\title{
Geological Society of America Bulletin
}

\section{An iron shuttle for deepwater silica in Late Archean and early Paleoproterozoic iron formation}

Woodward W. Fischer and Andrew H. Knoll

Geological Society of America Bulletin 2009;121;222-235

doi:10.1130/B26328.1

Email alerting services

\section{Subscribe}

Permission request click www.gsapubs.org/cgi/alerts to recieve free email alerts when new articles cite this article

click www.gsapubs.org/subscriptions/index.ac.dtl to subscribe to Geological Society of America Bulletin

click http://www.geosociety.org/pubs/copyrt.htm\#gsa to contact GSA

Copyright not claimed on content prepared wholly by U.S. government employees within scope of their employment. Individual scientists are hereby granted permission, without fees or further requests to GSA, to use a single figure, a single table, and/or a brief paragraph of text in subsequent works and to make unlimited copies of items in GSA's journals for noncommercial use in classrooms to further education and science. This file may not be posted to any Web site, but authors may post the abstracts only of their articles on their own or their organization's Web site providing the posting includes a reference to the article's full citation. GSA provides this and other forums for the presentation of diverse opinions and positions by scientists worldwide, regardless of their race, citizenship, gender, religion, or political viewpoint. Opinions presented in this publication do not reflect official positions of the Society.

\section{Notes}




\title{
An iron shuttle for deepwater silica in Late Archean and early Paleoproterozoic iron formation
}

\author{
Woodward W. Fischer ${ }^{*}$ \\ Department of Earth and Planetary Sciences, Harvard University, Cambridge, Massachusetts 02138, USA
}

\author{
Andrew H. Knoll \\ Department of Earth and Planetary Sciences, Harvard University, Cambridge, Massachusetts 02138, USA \\ Department of Organismic and Evolutionary Biology, Harvard University, Cambridge, Massachusetts 02138, USA
}

\begin{abstract}
Iron formations are typically thinly bedded or laminated sedimentary rocks containing $15 \%$ or more of iron and a large proportion of silica (commonly $>40 \%$ ). In the ca. 2590-2460 Ma Campbellrand-Kuruman Complex, Transvaal Supergroup, South Africa, iron formation occurs as a sedimentstarved deepwater facies distal to carbonates

but also generates considerable alkalinity in pore waters, driving precipitation of siderite from $\mathrm{Fe}^{2+}$ and respiration-influenced $\mathrm{CO}_{2}$. Silica liberated during iron reduction becomes concentrated in pore fluids and is ultimately precipitated as diagenetic mineral phases. This model explains many of the mineralogical, textural, and environmental features of Late Archean and earliest Paleoproterozoic iron formation.
\end{abstract} and shales. Iron minerals, primarily siderite, define the lamination. The silica primarily occurs as thin beds and nodules of diagenetic chert (now microcrystalline quartz), filling pore space and replacing iron formation minerals and co-occurring deepwater lithologies. Mechanisms proposed to explain precipitation of the iron component of iron formation include photosynthetic oxygen production, anoxygenic photosynthesis, abiotic photochemistry, and chemoautotrophy using $\mathrm{Fe}(\mathrm{II})$ as an electron donor. The origin and mechanism of silica precipitation in these deposits have received less attention. Here we present a conceptual model of iron formation that offers insight into the deposition of silica. The model hinges on the proclivity of dissolved silica to adsorb onto the hydrous surfaces of ferric oxides. Soluble ferrous iron is oxidized in the surface ocean to form ferric hydroxides, which precipitate. $\mathrm{Fe}(\mathrm{OH})_{3}$ binds silica and sinks from the surface ocean along with organic matter, shuttling silica to basinal waters and sediments. $\mathrm{Fe}(\mathrm{III})$ respiration in the sediments returns the majority of iron to the water column

†E-mail: wfischer@caltech.edu

*Present address: Division of Geological and Planetary Sciences, California Institute of Technology, 1200 E. California Blvd., Mail Stop 170-25, Pasadena, California 91125, USA.
Keywords: South Africa, iron cycle, banded iron formation, chert, Transvaal, Kuruman.

\section{INTRODUCTION}

Iron formation is a conspicuous and enigmatic rock type common in early Earth history. A vast literature exists on the topic of Precambrian iron formations (far greater than we can directly acknowledge here), and many concepts advanced herein were forecast in previous studies. For the interested reader, an illuminating cross section of common observations and persistent questions can be found in the following: James (1954), Lepp and Goldich (1964), Trendall and Blockley (1970), Beukes (1973), Trendall and Morris (1983, and chapters therein), Beukes and Klein (1992), Trendall (2002), Klein (2005), and Clout and Simonson (2005). The origin and nature of iron formation have captured a wide spectrum of scientific interest, including investigation of the enrichment processes that gave rise to large, economically viable ore bodies (Morris, 1980; Morris et al., 1980), potential origins of low velocity seismic zones at the core-mantle boundary (Dobson and Brodholt, 2005), secular trends in the oxidationreduction potential of the oceans and atmosphere (Macgregor, 1927; Cloud, 1968), and the biological factors, both proximal and distal, that figured in iron deposition (Harder, 1919; Cloud,
1973; Hartman, 1984; Walker, 1987; Brown et al., 1995; Konhauser et al., 2002).

Much of the previous intellectual focus has been directed at understanding the sources, transport, and precipitation of iron-bearing minerals, with somewhat less attention having been paid to the nature and origin of silica in iron formation. Here we explore the processes responsible for concentrating silica in basinal environments, as such processes should provide clues to, and be congruent with, other aspects of the origin and nature of iron formation. We report observations from deepwater chert and iron formation hosted within a Late Archean carbonate platform in the Northern Cape Province, South Africa. Using these and other observations of Late Archean and early Paleoproterozoic iron formation, we then develop a conceptual model for the deposition of iron formation that describes efficient shuttling of silica to deepwater sedimentary environments by the (biologically influenced) iron cycle. If correct, this model provides additional insight into the geobiology of the Archean Eon, a time for which the fossil record offers limited biological resolution.

\section{IRON IN IRON FORMATIONS}

Often defined as derived from chemical sediments, thinly bedded or laminated, with an anomalously high iron mineral content, and containing layers rich in chert, iron formation is in effect a uniquely Precambrian rock type (James, 1954; Trendall, 1983; Klein, 2005). Iron formations represent a style of sedimentation for which clear modern analogs do not exist (at least at a similar scale). Ideas concerning their origin are therefore fundamentally derived from a combination of first-principles inferences about iron- and silica-rich aqueous systems and observations of the mineralogies, textures, and geological relationships of iron

GSA Bulletin; January/February 2009; v. 121; no. 1/2; p. 222-235; doi: 10.1130/B26328.1; 7 figures. 
formations themselves. A number of hypotheses address the unique conditions of Archean and Proterozoic iron formation deposition. An accepted global theory of iron formation deposition is still lacking, however; and, indeed, it is unclear whether the diversity of iron formation types would ever accommodate such a theory (Simonson, 2003). Nonetheless, there are common threads to many hypotheses.

The ultimate source of $\mathrm{Fe}$ is commonly linked to increased regional or global, seafloor basaltic volcanism (e.g., Isley, 1995; Barley et al., 1997; Isley and Abbott, 1999; Barley et al., 2005), or changes in the composition of midocean-ridge hydrothermal systems (Kump and Seyfried, 2005). Many banded iron formations demonstrate rare earth and trace element distributions consistent with a high-temperature hydrothermal origin of metal ions (Jacobsen and Pimentel-Klose, 1988; Derry and Jacobsen, 1990; Klein and Beukes, 1992; Bau and Möller, 1993).

Another common assumption is that the oceans (at least at depth) were anoxic and therefore capable of transporting and concentrating $\mathrm{Fe}$ (II) dissolved in seawater (e.g., Cloud, 1968; Holland, 1973; Drever, 1974). Precipitation of iron minerals may have occurred either directly from anoxic seawater (forming siderite and $\mathrm{Fe}[\mathrm{II}]$-silicates) or following water column oxidation to ferric hydroxides (forming precursors to hematite and jasper) (Lepp and Goldich, 1964; Ewers, 1983; Beukes and Klein, 1992). Considerable attention has been given to the mechanisms responsible for ferrous iron oxidation, and several congruent possibilities exist. The primary oxidant may have been molecular oxygen $\left(\mathrm{O}_{2}\right)$, ultimately derived from oxygenic photosynthesis, which reacted with soluble ferrous iron either abiotically (equation 1), or via chemoautotrophy (equation 2) (Lepp and Goldich, 1964; Cloud, 1968; Cloud, 1973; Emerson and Revsbech, 1994; Konhauser et al., 2002):

$$
\begin{gathered}
4 \mathrm{Fe}_{(a q)}^{2+}+\mathrm{O}_{2}+10 \mathrm{H}_{2} \mathrm{O} \longrightarrow 4 \mathrm{Fe}(\mathrm{OH})_{3}+8 \mathrm{H}^{+} ;(1) \\
12 \mathrm{Fe}_{(a q)}^{2+}+\mathrm{O}_{2}+32 \mathrm{H}_{2} \mathrm{O} \longrightarrow \\
12 \mathrm{Fe}(\mathrm{OH})_{3}+2 \mathrm{CH}_{2} \mathrm{O}+24 \mathrm{H}^{+} .
\end{gathered}
$$

It has also been suggested that abiotic photochemical reactions were responsible for the oxidation of soluble Fe(II) (equation 3), using electrons from iron to reduce protons (from water) to hydrogen (Cairns-Smith, 1978; Braterman et al., 1983; Braterman et al., 1984):

$2 \mathrm{Fe}_{(a q)}^{2+}+6 \mathrm{H}_{2} \mathrm{O} \stackrel{\mathrm{h} v}{\longrightarrow} 2 \mathrm{Fe}(\mathrm{OH})_{3}+\mathrm{H}_{2}+4 \mathrm{H}^{+}$. .(3)
Finally, the discovery of anoxygenic photosynthesis with iron as a primary electron donor (Widdel et al., 1993; Ehrenreich and Widdel, 1994) gave concrete support to previous ideas that the biological oxidation of iron might occur in the absence of molecular oxygen, requiring only photocatalysis (equation 4) (Garrels et al., 1973; Baur, 1978; Hartman, 1984; Walker, 1987):

$$
\begin{aligned}
& 4 \mathrm{Fe}_{(a q)}^{2+}+\mathrm{CO}_{2}+11 \mathrm{H}_{2} \mathrm{O} \stackrel{\mathrm{h} v}{\longrightarrow} \\
& 4 \mathrm{Fe}(\mathrm{OH})_{3}+\mathrm{CH}_{2} \mathrm{O}+8 \mathrm{H}^{+} .
\end{aligned}
$$

Experiments and calculations of ferrous oxidation rates suggest that this microbial process (were it present) would have been sufficient to account for the sedimentary ferric iron flux required to produce large iron formations (Konhauser et al., 2002; Kappler et al., 2005; Konhauser et al., 2007b). In addition, molecular data from comparative biology imply that this type of photosynthesis (equation 4) was ancestral to oxygen-evolving cyanobacterial photosynthesis (Xiong et al., 2000) and thus may have been prevalent in the oceans before cyanobacteria rose to ecological prominence. Furthermore, in the absence of oxygenic photosynthesis, Fe(II) would have been the most abundant source of electrons for autotrophy (Walker and Brimblecombe, 1985; Kharecha et al., 2005; Canfield et al., 2006). It is critical that, in principle, the oxidation of ferrous iron does not require the presence of molecular oxygen in the environment. It is not yet clear whether oxygenic photosynthesis was present in Late Archean oceans; lipid biomarkers (if indigenous) suggest this was the case (Brocks et al., 2003a, b; but see Fischer et al., 2005, and Rashby et al., 2007), as do interpretations of lacustrine stromatolites from Western Australia (Buick, 1992). In general, however, the microfossil and stromatolite fossil records are equivocal (Knoll, 1996; Grotzinger and Knoll, 1999), and regardless of how biological proxies are interpreted, rock-based proxies suggest that very little if any $\mathrm{O}_{2}$ was present in the atmosphere or oceans (atmospheric $\mathrm{O}_{2}$ mixing ratio $<<10^{-5}$ ) (Rye and Holland, 1998; Rasmussen and Buick, 1999; Farquhar et al., 2000; Pavlov and Kasting, 2002; Ono et al., 2003; Bekker et al., 2004; Frimmel, 2005). Although limited during Late Archean time, oxygen appears to have been freely available in the atmosphere when the younger Paleoproterozoic (ca. $1900 \mathrm{Ma}$ ) circum-Superior Province and Nabberu Basin iron formations were deposited, and it may have played an important role in their deposition (Beukes and Klein, 1992). Here, our primary efforts are directed at understanding depositional processes (including ferrous iron oxidation) of iron formations present in Late Archean successions, particularly the Transvaal Supergroup of South Africa; however, we also revisit the distinction between older iron formations and those deposited ca. $1900 \mathrm{Ma}$, as their differences may record secular change in the chemical composition of the oceans and atmosphere.

\section{SILICA IN IRON FORMATIONS}

Although iron formations constitute the major crustal repositories of concentrated iron, they also contain a substantial proportion of silica, in the form of chert. Iron formations generally incorporate $>15 \mathrm{wt} \%$ total $\mathrm{Fe}$ (on average 30 wt $\%$ ), but commonly have silica concentrations of $>40 \mathrm{wt} \%$ (Klein, 2005). The source of silica must, like iron, ultimately derive from either low or high temperature rock weathering. Hamade et al. (2003) argued that Ge/Si data from iron formation of the Dales Gorge Member, Hamersley Group, require that the silica be sourced from low temperature continental weathering, in contrast to the iron, which was hydrothermally derived. The Precambrian oceans may have been close to saturation with respect to amorphous silica (Siever, 1992), and it has often been suggested that chert precipitated as a result of evaporative concentration (e.g., Trendall and Blockley, 1970; Drever, 1974; Garrels, 1987). The banding in iron formation was therefore argued to reflect times when ocean basins alternated between chert and iron mineral precipitation, perhaps reflecting climate variation, microbial blooms (e.g., Trendall and Blockley, 1970; Ewers and Morris, 1981), or, possibly, quasicontinuous background silica precipitation, with episodic deposition of iron derived from deep-ocean mixing (Hamade et al., 2003). Still others have proposed coprecipitation of iron and silica either by microbes (LaBerge et al., 1987) or abiotically (Ewers, 1983). Regardless of the mechanism responsible for concentrating silica in environments undergoing iron formation deposition, sedimentological observations make it clear that much of the chert formed during diagenesis of precursor sediments (Trendall and Blockley, 1970; Dimroth, 1976; Beukes, 1984; Simonson, 2003; Krapež et al., 2003).

Diagenetic chert deposition is common in rock successions of all ages; however, in stark contrast to younger Precambrian deposits characterized by peritidal silicification (Maliva et al., 1989), many Late Archean cherts were precipitated along with iron-bearing minerals in deepwater sedimentary environments. On a fundamental level, this implies that the Late Archean cycles of silica and iron were coupled in a fashion unseen in younger times. 


\section{SECULAR TRENDS IN SILICA SEDIMENTATION}

By mass flux, the silica cycle is one of the most important major element cycles intersecting the fluid Earth, and although silica does not undergo any redox transformations, it plays a key role in the acid-base chemistry of the oceans. A primary product of silicate weathering, silicic acid is perpetually delivered to the oceans. As long as some proportion of the cations carried along with silicic acid depart the oceans as carbonate salts (Walker et al., 1981), a supposition supported by the ubiquity of marine carbonates in the geologic record, silica is left behind to precipitate as chert. Chert commonly has a diagenetic origin wherever it is found in the sedimentary record. In many rock successions, amorphous silica was either redistributed intraformationally or precipitated directly to form chert nodules and beds during early diagenesis, and the paleoenvironmental distribution of early diagenetic chert closely reflects the processes that originally introduced silica to the sediments (e.g., Maliva and Siever, 1989; Knauth, 1994). The style of chert sedimentation has not been uniform throughout Earth history (Siever, 1957); rather, secular trends in the facies distribution of early diagenetic chert reveal the dynamic evolution of the marine silica cycle (Fig. 1) (Maliva et al., 1989).

Throughout the Phanerozoic Eon, silica deposition has largely been mediated by biology. Secular changes in the loci of Phanerozoic chert deposition reflect the evolution and ecology of silicifying organisms (Maliva et al., 1989; Schubert et al., 1997; Kidder and Erwin, 2001; Kidder and Mumma, 2003). In modern ocean basins, diatoms quantitatively control the removal of silica, maintaining silica concentrations in the oceans (surface water generally $<2$ $\mu \mathrm{M}$, deep water $\sim 100 \mu \mathrm{M}$ ) far below saturation with respect to amorphous silica $(\sim 1000 \mu \mathrm{M})$. Approximately $85 \%$ of this silica is removed to abyssal sedimentary environments, with the remainder on continental shelves (Tréguer et al., 1995). The abundance of pelagic and continental-margin bedded cherts suggests that diatoms have controlled silica deposition since their radiation in the Late Cretaceous to Paleogene (Kooistra et al., 2007). Prior to the radiation of diatoms, siliceous sponges and radiolarians sequestered silica into subtidal continental shelf and open ocean sedimentary environments (Maliva et al., 1989). Pelagic and hemipelagic cherts appear in similar context, whether constructed by diatoms or radiolarians. Such cherts are ultimately precipitated diagenetically by local remobilization of biogenic silica (Murray et al., 1992a, b; Bohrmann et al.,

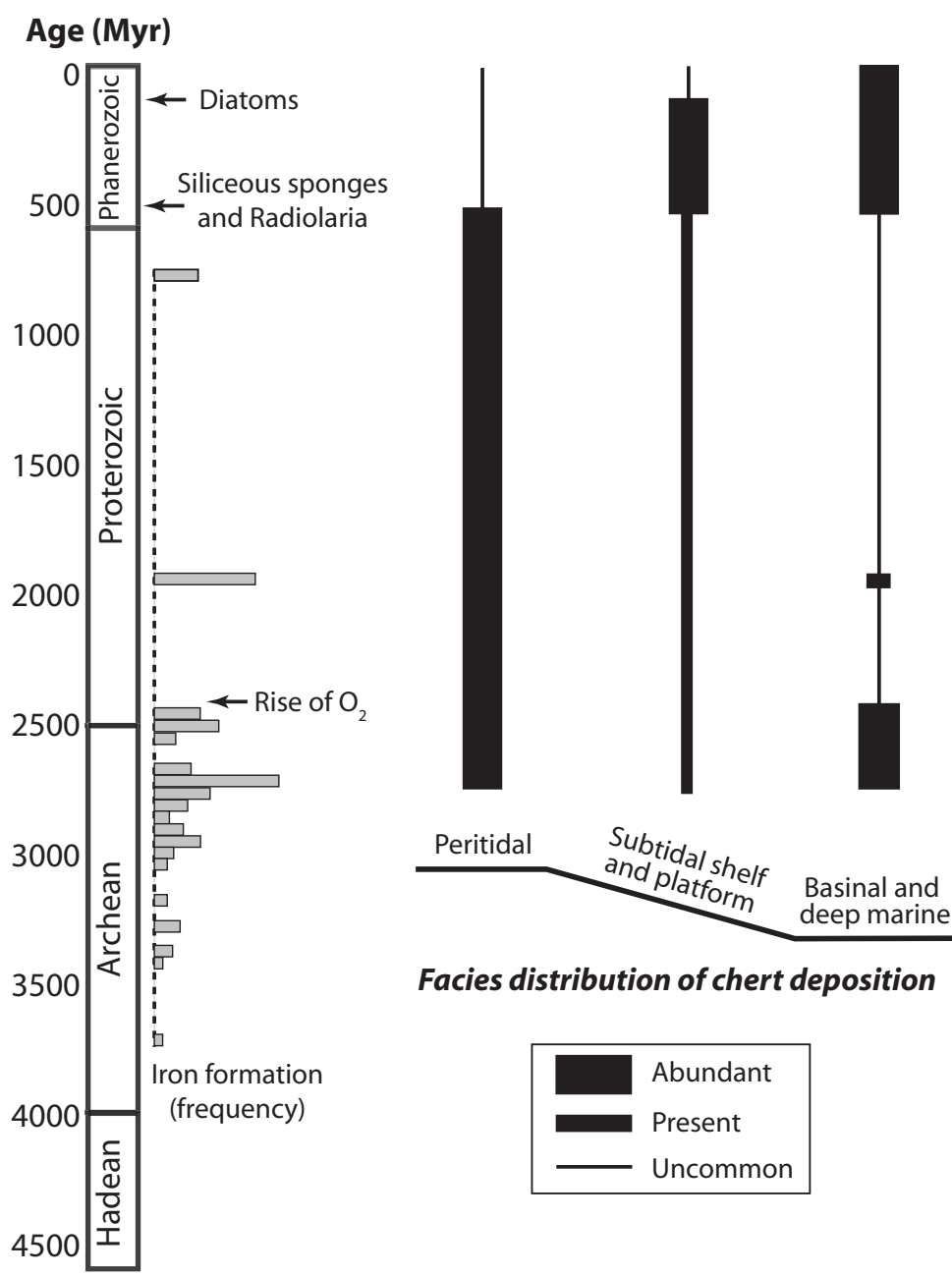

Figure 1. Generalized distribution of chert from Late Archean time to present. Compiled from Maliva et al. (1989), Siever (1991, 1992), Kidder and Erwin (2001), Perry and Lefticariu (2003), Kidder and Mumma (2003), and Maliva et al. (2005). The estimated frequency distribution of iron formation occurrences in the geologic record is modified from Isley and Abbott (1999).

1994), but the proximal flux of silica to deepwater environments is provided by sedimentation of diatom frustules, radiolarian tests, and, to a lesser extent, sponge spicules. In slight contrast with Cenozoic deposits, middle to late Paleozoic and Mesozoic pelagic cherts appear somewhat less commonly, and nodular chert in subtidal shelf and platform sediments is more abundant, presumably reflecting the greater abundance and influence of shallow-water siliceous sponges relative to today (Maliva et al., 1989; Maldonado et al., 1999). Despite these relatively subtle changes, siliceous skeletons provided a major removal process for seawater silica during much of Phanerozoic time. In consequence, the facies distribution of nodular and bedded cherts commonly reflects the ecology of silica-secreting organisms (Fig. 1) (Maliva et al., 1989).

In the Precambrian marine silica cycle, quantitatively significant skeletal sinks were absent (Siever, 1957; Perry and Lefticariu, 2003). In the absence of skeletal removal, oceanic silica concentrations were considerably higher, perhaps close to amorphous silica saturation (Siever, 1991, 1992), and the process of removal was localized to the margins of the oceans, as indicated by the prevalence of peritidal chert in Proterozoic carbonate successions (Maliva et al., 1989; Maliva, 2001; Maliva et al., 2005). Commonly silicified lithologies include stromatolites, oolites and other grainstones, and intraformational conglomerates (which commonly mark sequence-boundary exposure surfaces). Peritidal 
cherts commonly originated by direct pore fluid precipitation and/or carbonate replacement during early diagenesis, preserving ghosts and inclusions of carbonate precursors (Maliva et al., 2005). Among other things, this early diagenetic silicification was responsible for the exceptional fossil preservation in Proterozoic cherts (e.g., Knoll, 1985; Knoll et al., 1991). Although the exact mechanism of replacement and precipitation is still not well understood (Knauth, 1994), the abundance of early diagenetic silicification in tidal flat environments, and a relative paucity of chert in distal facies, support the idea that evaporative processes played a principal role in concentrating and depositing silica in the shallowest parts of the oceans (Maliva et al., 1989; Maliva et al., 2005). Such shallow water cherts are common in Precambrian carbonates of all ages, largely disappearing only with the radiations of sponges and radiolarians in the early Paleozoic (Fig. 1) (Maliva et al., 1989; Kidder and Mumma, 2003). Offshore subtidal cherts are less common in the Proterozoic, and infrequently preserve microfossils (Maliva et al., 1989, 2005). Pelagic and hemipelagic cherts analogous to Phanerozoic radiolarian or diatom bedded cherts are rare or absent (Siever, 1991). Indeed, for over two billion years of Earth history there are only two known exceptions that, in essence, prove the rule: the Discovery Chert, a silicified basinal shale of Mesoproterozoic age (Buick and Knoll, 1999), and the EdiacaranCambrian boundary silicilyte from the South Oman Salt Basin (e.g., Amthor et al., 2005). For the earlier Precambrian, however, it appears that depositional patterns were different.

From the standpoint of typical Precambrian chert sedimentation, Archean and Paleoproterozoic banded iron formations are unusual (Fig. 1) (Siever, 1991; Perry and Lefticariu, 2003; Maliva et al., 2005). Late Archean and early Paleoproterozoic iron formations, such as the well-studied examples from the Transvaal Supergroup and Hamersley basin, are commonly recognized as deepwater basinal deposits (e.g., Beukes, 1984; Beukes and Klein, 1992; Blake and Barley, 1992; Krapež et al., 2003). In addition to the chert contained within iron formation sensu stricto, deepwater nodular and bedded chert is also prevalent in adjacent basinal rock types (i.e., deepwater shales, carbonates, and microbialites) (e.g., Beukes, 1987; Krapež et al, 2003; Pickard et al., 2004). This facies distribution implies that evaporative concentration is an unlikely mechanism for their origin. Were it not for the iron, these deposits might be most similar to the deepwater biogenic cherts of the Phanerozoic, though for the Archean and Paleoproterozoic we cannot call on skeletons to have deposited silica in deep basinal settings. A major question thus arises: what mechanism was responsible for concentrating dissolved silica in deepwater sedimentary environments during Archean and early Paleoproterozoic time? A reasonable first order assumption is that the cycles of iron and silica were somehow coupled, but what was the nature of their association?

\section{IRON FORMATION AND DEEPWATER CHERT IN THE CAMPBELLRAND- KURUMAN COMPLEX}

Some of the most useful insights into the deposition of iron formation derive from their geological contacts with other rock types (Ojakangas, 1983; Simonson, 1985; Hoffman, 1987; Pickard et al., 2004). Here we report observations on the geological context and petrology of Late Archean and earliest Paleoproterozoic iron formation from the Transvaal Supergroup in South Africa.

The South African Transvaal Supergroup occurs in two structural basins on the Kaapvaal Craton (Griqualand West and Transvaal proper); however, the original deposit probably extended across the entire $600,000 \mathrm{~km}^{2}$ surface of the craton (Fig. 2) (Button, 1973; Beukes, 1987; Sumner, 1995). The succession remains flat lying and largely undeformed across the craton, with significant deformation limited to areas in close proximity to the Bushveld Igneous Complex and the fold belt along the western edge of the Kaapvaal craton. Metamorphism of the Transvaal Supergroup is generally below greenschist facies equivalent (Button, 1973; Miyano and Beukes, 1984), with greater alteration only in rocks near the Bushveld Complex.

The Transvaal succession rests disconformably atop volcanics and intercalated sedimentary rocks of the $2,714 \pm 8 \mathrm{Ma}$ (Armstrong et al., 2001) Ventersdorp Supergroup. In Griqualand West, the Transvaal is divided into three subgroups (Fig. 2). The ca. 2650 Ma Schmidtsdrif Subgroup (dates inferred from correlation with Transvaal Basin equivalents; Barton et al., 1995; Walraven and Martini, 1995) consists of mixed siliciclastic and carbonate units. The succeeding Campbellrand Subgroup (ca. 2588-2520 Ma; Barton et al., 1994; Sumner and Bowring, 1996; Altermann and Nelson, 1998) circumscribes a broad, 2 -km-thick marine platform that originated as a carbonate ramp, which subsequently advanced into a mature, steeply rimmed carbonate platform that extended across the entire Kaapvaal Craton (Beukes, 1987; Sumner and Beukes, 2006). Ultimately the Campbellrand Platform drowned following a major trangession that heralded the onset of major iron formation deposition across the Kaapvaal Craton, recorded by the ca. 2460 Ma (Pickard, 2003)
Kuruman Iron Formation of the Asbestos Hills Subgroup. In general, the Campbellrand Platform and Kuruman Iron Formation reflect the passive accumulation of chemical precipitates across the Kaapvaal Craton during Late Archean time. We refer to these deposits collectively as the Campbellrand-Kuruman Complex.

\section{Large-Scale Observations}

Previous studies of the gradational transition from carbonate platform to iron formation in the Campbellrand-Kuruman Complex suggested that this pattern reflects the succession of sedimentary facies in a deepening-upward sequence, rather than a secular change in the seawater chemistry of the basin (Beukes, 1984, 1987; Klein and Beukes, 1989; Beukes et al., 1990; Beukes and Klein, 1992; Simonson and Hassler, 1996; Sumner, 1997). If correct, this implies that iron formation was constantly deposited as a deepwater facies adjacent to the Campbellrand Platform, and only accumulated across the craton in abundance as rates of carbonate production declined and the platform drowned.

To test this interpretation further, we examined two new diamond drill cores, GKP01 and GKF01, collected as a part of the Agouron Drilling Project (Fig. 2). Such cores are exceedingly valuable, in part to combat challenges presented by pervasive surficial oxidation in South Africa (often penetrating to depths of $>20 \mathrm{~m}$ ), but also to reveal geological relationships that are not adequately recorded in outcrop. A segment of the ancient platform margin preserved in Griqualand West (northeast of Prieska) connects the deepwater (several hundred meters to $>1 \mathrm{~km}$ water depth) slope and basinal facies exposed near Prieska to the shallow-water Campbellrand carbonate platform. Here, the two cores, GKP01 and GKF01, intersect the paleogeographic lower and upper slope, respectively. Detailed descriptions of the sequence stratigraphy; lithologies; sedimentology; and major, minor, and trace element geochemistry of the two Agouron cores (GKP01 and GKF01) can be found in Schröder et al. (2006) and Sumner and Beukes (2006). We include data from an additional core, BH1Sacha, which captures platform-top, shallowwater facies for comparison. Description of the sedimentology and stratigraphy of BH1-Sacha can be found in Altermann and Siegfried (1997). Carbon isotopic analysis and discussion of the stratigraphy of all three cores can be found in Fischer et al. (2008).

The sedimentology, sequence stratigraphy, and asymmetrical occurrence of iron formation across the platform margin all support the interpretation of iron formation as a deepwater sediment-starved facies occurring distal to 


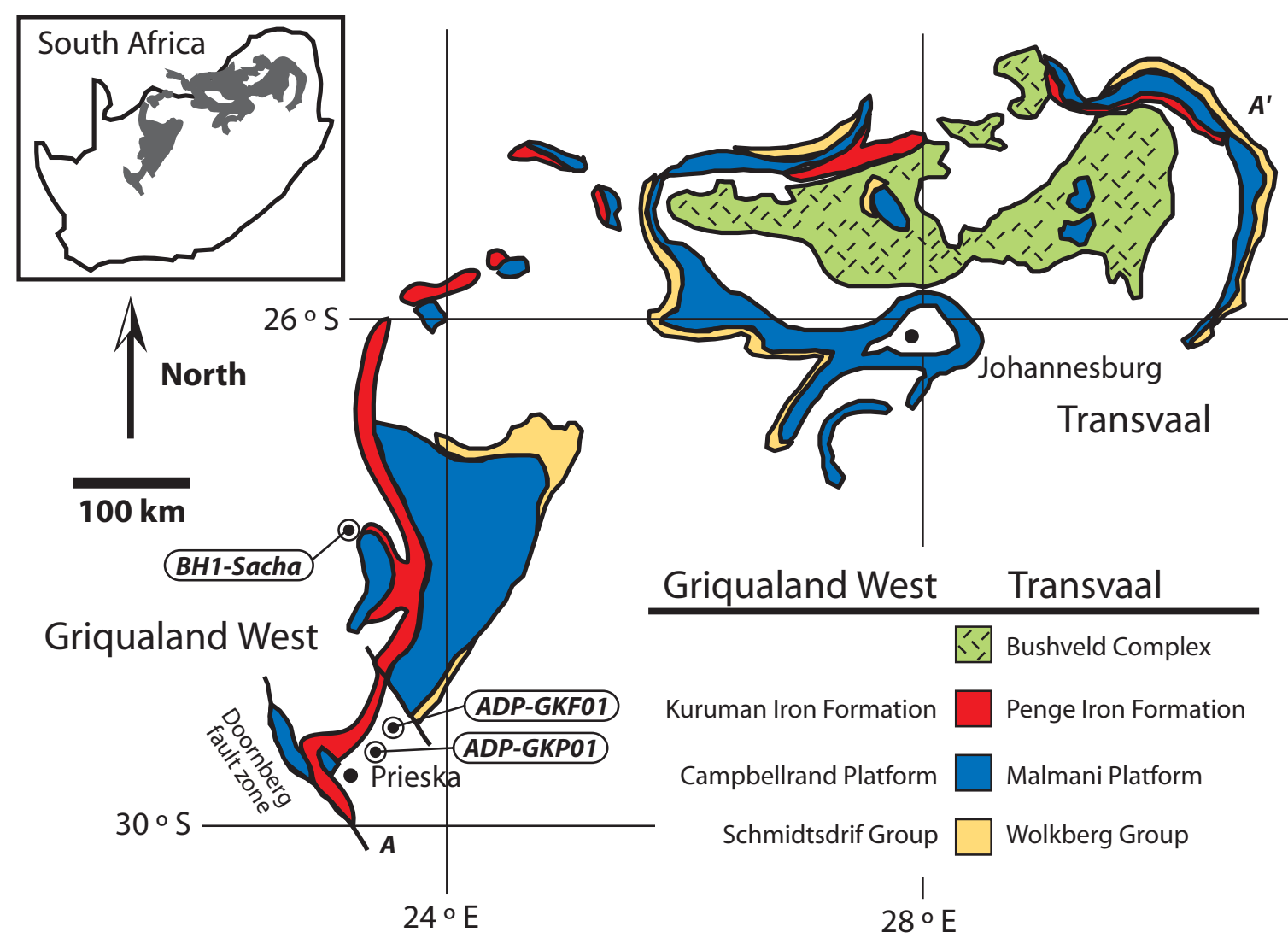

Figure 2. Distribution of the Transvaal Supergroup preserved on the Kaapvaal Craton, modified from Sumner and Beukes (2006). A segment of the Campbellrand Platform margin is preserved in Griqualand West near Prieska. Locations of drill cores GKP01, GKF01, and BH1-Sacha are shown.

platform-derived sediment (including shales) (Fig. 3). Throughout the Campbellrand-Kuruman Complex, iron formation is thinly bedded or laminated and contains no orbital bed forms. Lithologies that commonly interfinger in conformable contact with iron formation include shales, carbonate turbidite grainstones, plumose and fenestral microbialites, laminated microbialites, and bedded chert. GKP01 and GKF01 record the familiar gradational stratigraphic pattern of carbonates giving way to shales and, eventually, iron formation (Fig. 3, $<400 \mathrm{~m}$ depth). In both cores an increasing proportion of nodular and bedded chert accompanies this upsection trend, which is reasonably recognized as a deepening upward succession (Schröder et al., 2006). In the easterly sections (e.g., BH1-Sacha), where the platform developed, iron formation appears only twice in the stratigraphic succession. The thick Kuruman Iron Formation (subsequently eroded and replaced by Permian tillites in BH1-Sacha, but present elsewhere in Griqualand West) was deposited after drowning of the Campbellrand Subgroup carbonate platform. In addition, a thin iron formation unit, the Kamden Member, occurs lower in the succession, dividing the Campbellrand Platform. This marker unit is interesting because it was deposited as a result of an earlier strong transgression (and major sequence boundary; Beukes, 1987; Altermann and Siegfried, 1997; Schröder et al., 2006; Sumner and Beukes, 2006) across the platform. Although carbonate precipitation would eventually recover, the Kamden event shares many features with the terminal Campbellrand drowning, albeit at a smaller scale. This is in contrast to cores GKP01 and GKF01 in which thinly bedded chert and iron formation are much more common (particularly in the lower slope of GKP01) and are developed preferentially at sequence-stratigraphic-boundary (flooding or hiatal) surfaces (Schröder et al., 2006).

Figure 4 summarizes the relationships among iron-poor carbonates, iron-rich carbonates and shales, and iron formation in a southwest-trending cross section across the Campbellrand-Kuruman Complex platform margin in Griqualand West, updated from Beukes (1987). Shallowwater carbonates tend to be iron poor in contrast with deepwater carbonates, which contain substantial iron. These data support the commonly held view that during Late Archean time, iron was effectively removed from surface waters, presumably by oxidation processes, while the deep oceans maintained a reservoir of dissolved iron (e.g., Klein and Beukes, 1989; Beukes and Klein, 1992; Simonson and Hassler, 1996; Kappler et al., 2005). If ferrous iron was the primary electron donor for autotrophy in Archean oceans (e.g., Widdel et al., 1993), primary production in essence must have been electron limited (e.g., Canfield et al., 2006). Interestingly, manganese does not share this same distribution (Beukes, 1987); rather, it was quantitatively removed as $\mathrm{Mn}$ (II) on shallow-water carbonates. Because the standard potential of $\mathrm{Mn}^{2+} / \mathrm{MnO}_{2}$ requires a strong oxidant (such as oxygen or nitrate), it suggests that although surface ocean environments were capable of efficiently oxidizing iron, they did not commonly oxidize Mn(II).

Sequence stratigraphic analysis and platform architecture indicate that Campbellrand-Kuruman Complex iron formation was deposited in a hemipelagic setting under sediment-starved 

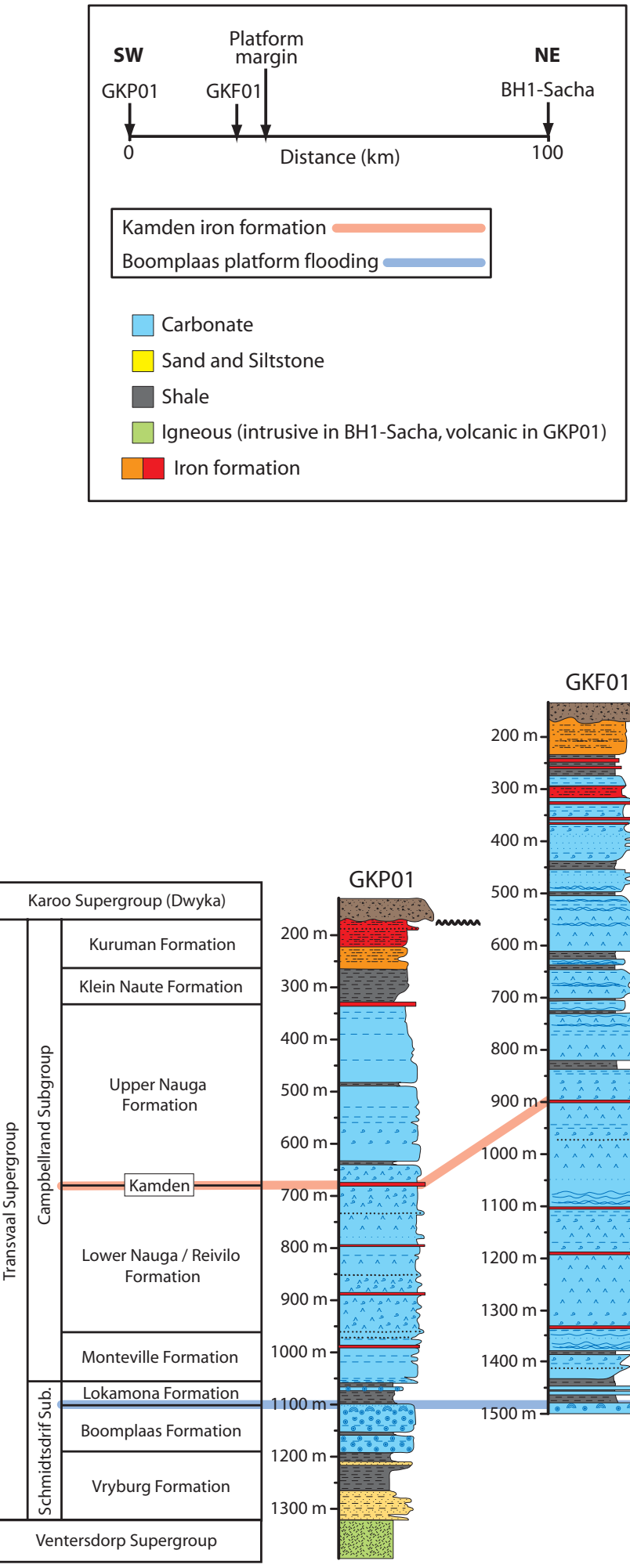

BH1-Sacha

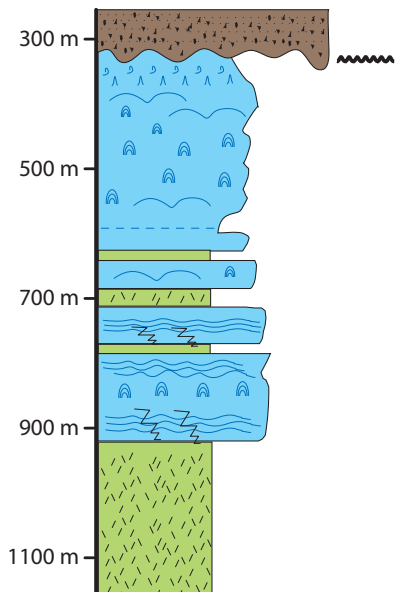

Figure 3. Lithostratigraphy of cores GKP01, GKF01, and BH1-Sacha. Nomenclature of stratigraphic units in Griqualand West is depicted alongside core GKP01. The different cores were aligned using a sequence stratigraphic datum, the flooding of the Boomplaas Formation (a thin carbonate platform in the Schmidtsdrif Subgroup). An additional line of correlation was drawn connecting the Kamden Member iron formation of the Lower Nauga-Reivilo Formation, a robust lithologic marker present in all three cores. All three cores exhibit an erosional unconformity where the upper Transvaal Supergroup was removed, followed by the deposition of Permian tillites of the Karoo Supergroup. In GKP01 and GKF01 the lower Kuruman Iron Formation is still preserved; however, in BH1Sacha the entire Kuruman Iron Formation was excised, and the young tillites rest directly on the top of the Campbellrand Subgroup. Included are the relative distances between the three cores projected onto a section line (e.g., Fig. 2, A to $\mathrm{A}^{\prime}$ ) orthogonal to the platform margin. 


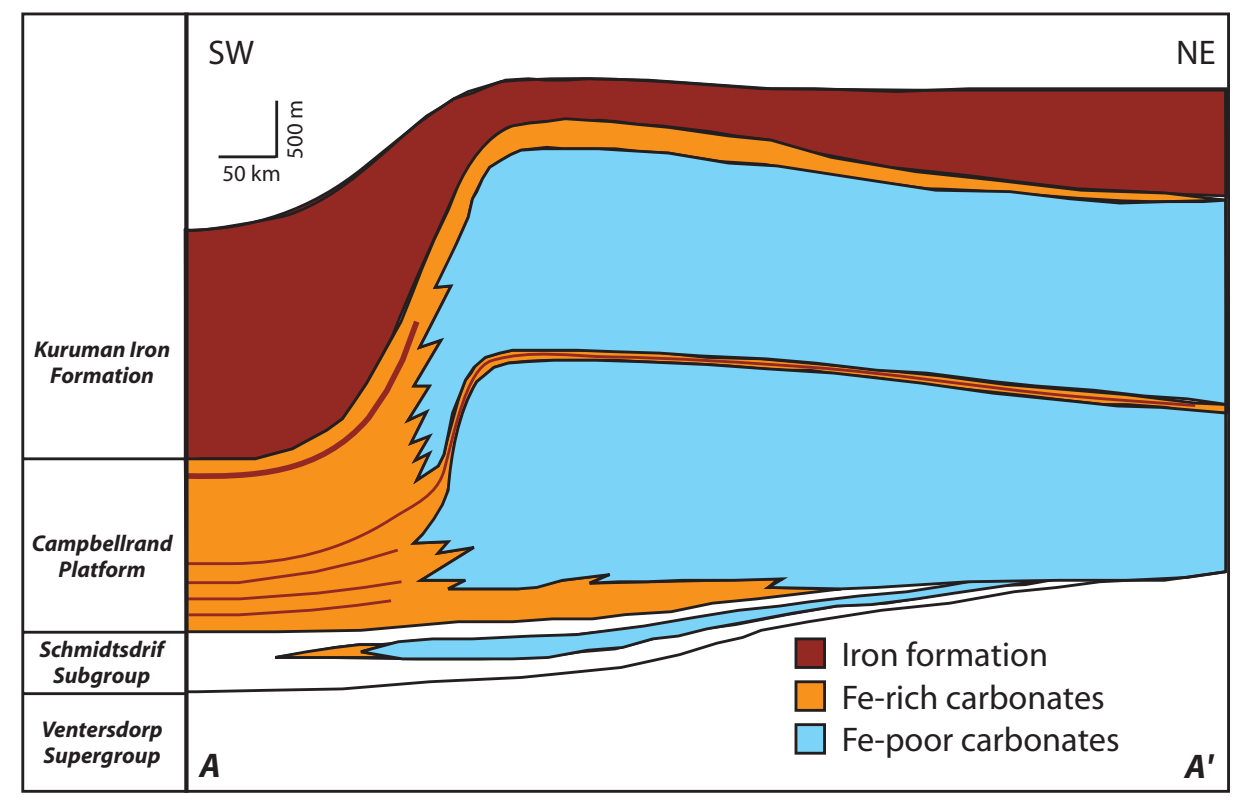

Figure 4. A northeast-southwest-trending cross section across the Campbellrand Platform margin (Fig. 2, A to $\mathbf{A}^{\prime}$ ) shows relationships between iron-poor carbonates, iron-rich carbonates (and shales), and iron formation. Modified from Beukes (1987), integrating observations from this study along with additional data (Klein and Beukes, 1989; Schröder et al., 2006; Sumner and Beukes, 2006). The division between iron rich and iron poor is $\sim 1 \mathrm{wt} \% \mathrm{FeO}$.

conditions, and likely represents typical deepwater sedimentation in this Late Archean and earliest Proterozoic ocean basin (Beukes, 1984, 1987). Ultimately, it was only the cessation of carbonate precipitation coupled with ongoing subsidence that allowed these deposits to expand across the Kaapvaal Craton.

\section{Small-Scale Observations}

All iron formations have undergone strong diagenetic (and in most cases, metamorphic) transformations, altering both mineralogy and textural relationships. The challenge therefore is to infer as much as possible about the state of iron formation at its moment of deposition, given the relationships between extant minerals and textures.

In contrast with outcrop and quarry exposures, the Campbellrand-Kuruman Complex iron formations observed in cores contain a high proportion of $\mathrm{Fe}(\mathrm{II})$-bearing minerals (Figs. 5A and $5 \mathrm{~B}$ ). This primarily reflects diagenetic processes of oxidative weathering that attacked outcrops, and ore-forming enrichment; however, Klein and Beukes (1989) indicated that a true environmental trend occurred in the oxidation state of the Campbellrand-Kuruman Complex iron formation, with iron oxides more common with increasing distance (and water depth) from the platform margin.
The most conspicuous sedimentary structures in the iron formation are submillimeter- to millimeter-scale laminations, and oblate chert nodules and beds oriented parallel or subparallel to bedding (Figs. 5F-H) (Beukes, 1984). Fine-grained hematite and siderite spheroids define laminae in iron-rich beds, and these laminations can be traced through chert, commonly displaying differential compaction, some as high as $80 \%-90 \%$ (Beukes, 1984; Simonson, 2003; Clout and Simonson, 2005). By following many of the mesobanded chert beds along strike, one can commonly demonstrate that they are nodular in origin (Beukes, 1984). These features strongly imply that silica was transported to basinal sediments and then remobilized and precipitated during early diagenesis, preserving pore fluid and replacing precursor sediments. Early diagenetic chert is also present in adjacent deepwater lithologies as oblate nodules and lenses, spherical blebs, and rip-up clasts (Fig. 5F). Rip-ups suggest that silicification occurred at or near the seafloor, creating hardgrounds (Krapež et al., 2003). Not all chert in the basinal Campbellrand-Kuruman Complex formed during early diagenesis. Late stage (post compaction) silicification created the chert matrix common to iron formation and many basinal mudstones.

Typical minerals in the GKP01 and GKF01 iron formation include siderite, iron silicates (such as greenalite), and chert. The most common oxide mineral is magnetite (mixed valence); in general, hematite (and jasper) is uncommon. Much of the magnetite and ankerite present is euhedral and displays discordant relationships both with indigenous kerogen and with hematite and siderite laminae (Beukes et al., 1990). Wavy-bedded magnetite is also common and cuts across primary bedding (Fig. 5E). On occasion, hematite lamination within early diagenetic chert nodules can be traced into magnetite outside the nodule (Beukes, 1984). This indicates that much of the magnetite mineralization occurred by replacement during late diagenesismetamorphism (Han, 1978; Beukes, 1984; Beukes et al., 1990). Of the minerals present in the Campbellrand-Kuruman Complex iron formation, hematite, siderite, iron silicates (greenalite), and chert all display petrographic textures that imply their presence in the sediment during early diagenesis (Figs. 5C and 5D). These minerals define a disequilibrium assemblage that cannot easily be explained by precipitation from a uniform fluid (Krapež et al., 2003). In addition, the carbon isotopic composition of these siderites is highly variable, from $\sim 0 \%$ (VPDB [Vienna Peedee belemnite]) to $-15 \%$, in contrast to both shallow- and deepwater carbonate precipitates (Perry and Tan, 1972; Beukes et al., 1990; Kaufman et al., 1990; Kaufman et al., 1996; Fischer et al., 2008). This suggests that siderite at least was deposited during early diagenesis from pore fluids influenced by the remineralization of organic matter, likely involving dissimilatory iron reduction (Walker, 1984; Fischer et al., 2008). This interpretation is supported by iron isotope ratios of siderite from Late Archean and early Paleoproterozoic iron formations in South Africa and Western Australia (Yamaguchi et al., 2005; Johnson et al., 2008).

\section{Iron Formation Banding}

Conspicuous banding has been recognized in iron formation at several different scale lengths (e.g., Trendall and Blockley, 1970). Each of these types of banding is observed in the Campbellrand-Kuruman Complex iron formations. Macrobanding occurs at a scale of meters and is defined by the interfingering of iron formation with shales, carbonate turbidites, and other platform-derived sediment. This style of banding can be understood in a sequence stratigraphic context. It was likely created by the episodic delivery during lowstand of platform and slope derived sediment into basinal areas that accumulated iron formation (Fig. 3, GKP01 and GKF01 <350 m) (e.g., Pickard et al., 2004). At the other end of the size spectrum, microbanding (commonly submillimeter to millimeter 

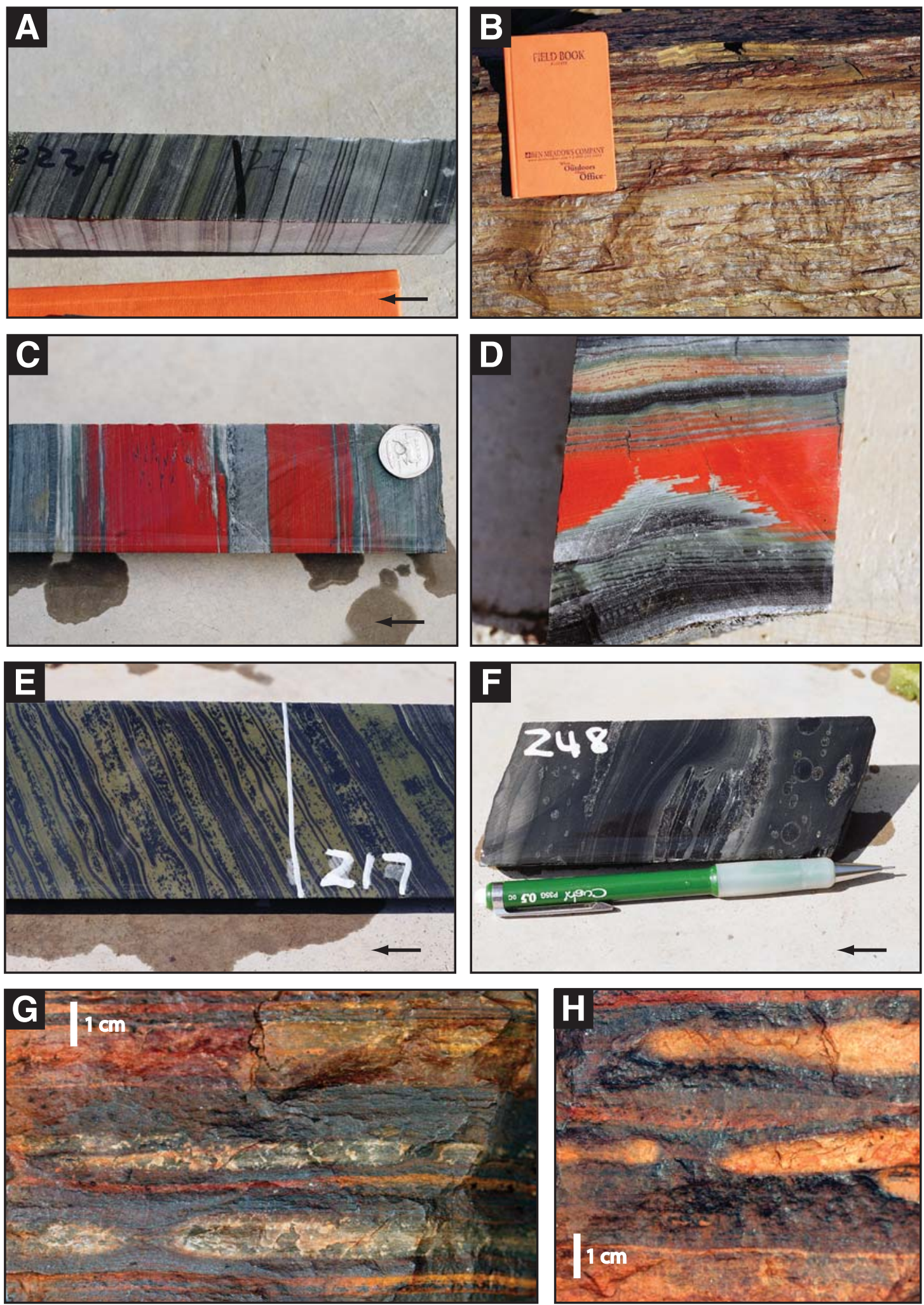

Figure 5. Examples of iron formation and deepwater chert in the Campbellrand-Kuruman Complex. (A) Typical banded iron formation in core. Siderite-magnetite-chert with rare iron silicate-rich laminations. Quarter core is $\sim 2.5 \mathrm{~cm}$ wide. (B) Kuruman Iron Formation in outcrop. (C, D) Uncommon hematite and jasper-rich microbands in cores GKP01 and GKF01 preserved in chert. Laminae grade laterally from iron oxides into siderite and iron silicates. Core sample is $\mathbf{4 7 . 6} \mathrm{mm}$ in diameter. (E) Wavy magnetite laminae cut across millimeter-scale primary bedding. Core sample is $70 \mathrm{~mm}$ in diameter. (F) Early diagenetic chert nodules in shale. The black nodules are thinly outlined by pyrites that postdate the chert. (G, H) Early diagenetic chert nodules in iron formation; bounding laminations display differential compaction. 
scale) may reflect episodic deposition from the water column (e.g., Trendall and Blockley, 1970), resedimentation of grains formed elsewhere (Krapež et al., 2003), or both (Beukes, 1984; Beukes et al., 1990). Each microband would, therefore, represent a single depositional event. What is clear, however, is that the microbands are mineralogically heterogeneous, both laterally and vertically (Figs. 5C and 5D). Thus, whereas microbands display textures consistent with the physical processes of sedimentation, their chemistry was significantly altered during diagenesis. Between these two extremes is mesobanding, which is commonly defined by centimeter-scale chert beds. As noted above, these chert mesobands can be demonstrated to have formed during early diagenesis, at and/or below the seafloor (Beukes, 1984; Krapež et al., 2003). In general, the petrographic textures displayed by silica in Campbellrand-Kuruman Complex iron formation and adjacent sedimentary lithologies reveal a diagenetic origin. As precursor sediments that gave rise to iron formation must have contained a substantial proportion of silica, hypotheses which hold that ocean basins switched back and forth between iron and silica deposition are not required.

\section{CONCEPTUAL MODEL OF LATE ARCHEAN IRON FORMATION DEPOSITION}

As mentioned above, there are many ideas concerning the origin of iron formation. In this section we propose a conceptual model that couples the anomalous deepwater silica to the mineralogical, textural, and environmental features of iron formation. Following suggestions made by Ewers (1983) based on the work and ideas of Harder $(1964,1965)$, and Harder and Flehmig (1970), our model hinges on the proclivity of dissolved silica to bind to ferric hydroxides.

Many experiments have demonstrated that dissolved silica exhibits a strong affinity for the hydrous surfaces of trivalent metal oxides, including ferric hydroxides (Okamoto et al., 1957; Huang, 1975; Sigg and Stumm, 1981; Swedlund and Webster, 1999; Davis et al., 2001; Davis et al., 2002; Fein et al., 2002; Yee et al., 2003). Sorption occurs by ligand exchange and thus depends on silica concentration, $\mathrm{pH}$, and the number of available $=\mathrm{FeOH}$ sites, features that are not well constrained for ancient conditions. It is important, however, that (1) silica readily adsorbs to ferric hydroxides across a wide range of conditions, up to and above equimolar ratios (Davis et al., 2002), and (2) ferric hydroxides will tend to bind a high proportion of available silica even in solutions significantly undersaturated with respect to silica

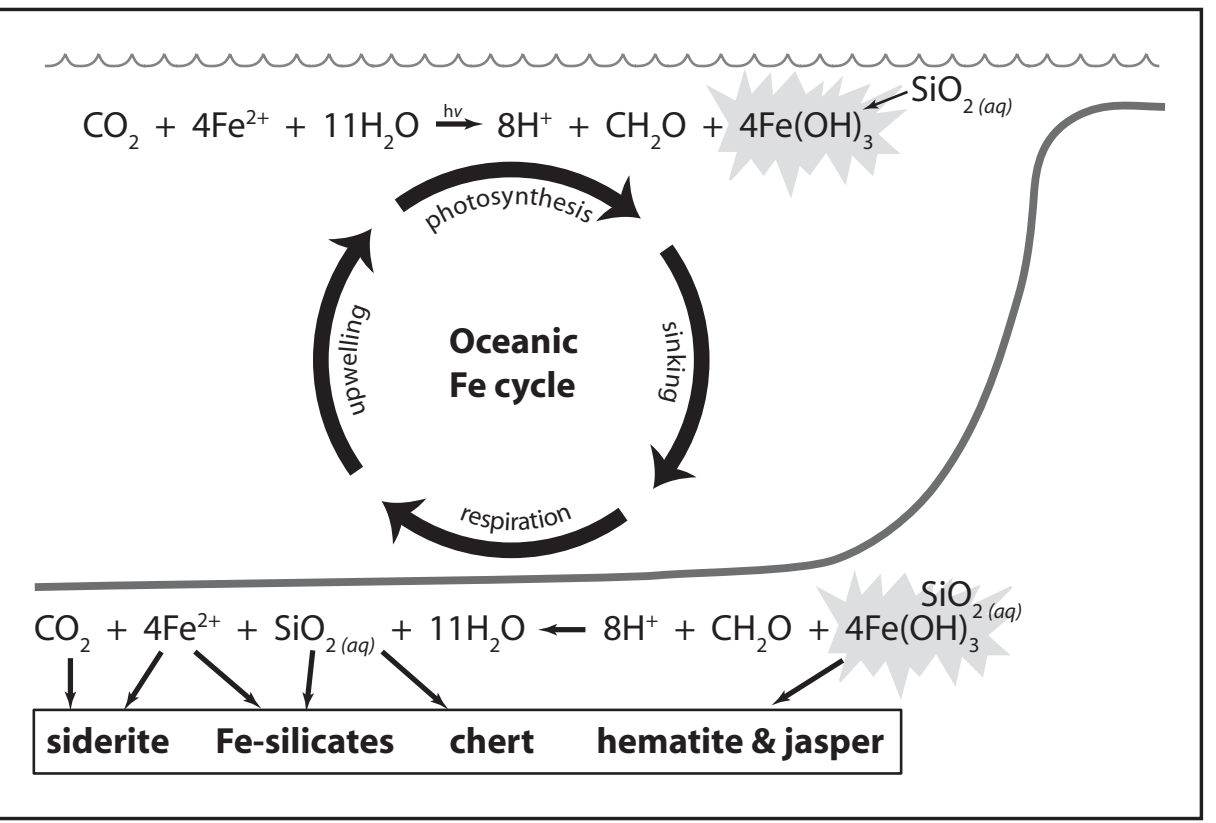

Figure 6. Conceptual model of Late Archean and earliest Paleoproterozoic iron formation deposition, derived from the biological oceanic iron cycle. See text for description and explanation.

(e.g., Fein et al., 2002). Much of the interest in this process has focused on the effect that silica has on hindering the sorption of other anions of interest (e.g., arsenate; Davis et al., 2001). For example, Konhauser et al. (2007a) have argued that during Archean time, silica adsorption on iron oxyhydroxides led to the competitive exclusion of phosphate. Here we emphasize that silica adsorption on ferric hydroxides may have been an important mechanism for sequestering silica to deepwater sediments along with iron in Late Archean ocean basins (Fig. 6).

A diagram of our model is shown in Figure 6. We assume that the oceans were anoxic and capable of transporting and concentrating ferrous iron. Whenever waters carrying $\mathrm{Fe}^{2+}$ intersected the photic zone, the iron was oxidized. The mechanism of oxidation can, in principle, be any of those discussed previously as long as they effectively transduce electrons from iron to organic matter (in order to drive subsequent iron respiration in the sediments). This could be abiotic photochemical oxidation, if the $\mathrm{H}_{2}$ produced were fixed into organic matter, or possibly $\mathrm{O}_{2}$ from oxygenic photosynthesis, as long as the oxygen was effectively consumed by iron oxidation. Though current data are insufficient to rule it out, we do not currently favor oxygenic photosynthesis, in part because it is not supported by evidence for $\mathrm{Mn}^{2+}$ in surface waters, but also because the oxidant produced $\left(\mathrm{O}_{2}\right)$ is poorly soluble in seawater and will tend to escape to the atmosphere, conflict- ing with other geological data and hindering the effective transduction of electrons. For the purpose of this discussion we consider the oxidation by anoxygenic photosynthesis, wherein $\mathrm{CO}_{2}$ is fixed into organic matter using electrons from ferrous iron (equation 4). Assuming that the $\mathrm{pH}$ of seawater was not strongly acidic (i.e., was $>4$ ), ferric iron produced by this reaction would rapidly undergo hydrolysis and precipitate as ferric hydroxides. Dissolved silica readily adsorbs to the ferric hydroxide surface, generating siliceous ferric hydroxide particles that sink from surface ocean waters to the sediments along with organic matter.

The mineralogy and carbon isotopic composition of siderite indicate that processes within the sediments must both reduce iron back to $\mathrm{Fe}(\mathrm{II})$ and oxidize organic matter. Aerobic respiration would have been unlikely in these anoxic basinal settings; moreover, it cannot account for the reduction of ferric iron. Dissimilatory iron reduction is an attractive process for explaining these coupled observations. In addition, biological iron reduction may have been instrumental in the transformation and precipitation of other mineral phases during early diagenesis. In the sediments (and likely in the water column during transport) iron respiration takes place. As the ferric oxides undergo reductive dissolution, the silica is liberated. A significant proportion of these products likely diffuse back to the water column, where they are advected to the surface during upwelling to begin the cycle again. 
Sediments that contain insufficient organic matter to reduce the siliceous ferric hydroxides form the precursors to hematite iron formation and jasper. Because iron reduction is a strong alkalinity pump, it will tend to drive the precipitation of siderite (a rather insoluble carbonate salt). This siderite will therefore carry some isotopic memory of the organic carbon used to reduce the oxidized iron. Silica and ferrous iron can combine to form early diagenetic iron silicates such as greenalite, and dissolved silica can migrate locally to form early diagenetic cherts. Additional pore fluid silica will likely derive from desorption during maturation of unreduced ferric hydroxides to ordered anhydrous minerals.

This model accounts for many critical features observed in Campbellrand-Kuruman Complex iron formations, including the mesoscale banding, the occurrence and distribution of chert in basinal settings, the predominance of $\mathrm{Fe}$ (II)-bearing minerals, and the carbon isotopic composition of siderite. Additionally, if the flux of organic matter to the sediment-water interface was, like today, depth-dependent, then our model also suggests that the accumulation of iron formation containing abundant iron oxides should be located in the deepest water (where sedimentary organic matter is insufficient to reduce all the iron); this may explain the aforementioned distribution observed by Klein and Beukes (1989). In this regard, it is interesting to note that in the Campbellrand-Kuruman Complex, siderite facies iron formation contains organic carbon concentrations more than an order of magnitude higher (with some concentrations $>0.5 \mathrm{wt} \%$ ) than oxidized facies iron formation (Klein and Beukes, 1989; Beukes et al., 1990; Fischer et al., 2008).

\section{SUMMARY AND DISCUSSION}

Previous studies of banded iron formation focused largely on iron transport, oxidation, and mineralization in iron formation, and with good reason, because those processes indicate a transition in the oxidation-reduction potential of the oceans. In contrast, we focused on the nature of the silica that is so conspicuous in iron formations. In the context of typical Proterozoic chert deposition, the abundant silica in iron formation is environmentally unusual and requires explanation. We have proposed a model for the origin of Late Archean and earliest Paleoproterozoic iron formation with links to the silica cycle. The model relies on efficient shuttling of silica to deepwater sedimentary environments by the (biological) iron cycle. We conclude that as long as iron was oxidized in the surface ocean and sank into basinal sedimentary environments, it would have acted as an effective agent for deliv- ering silica to deepwater sedimentary environments. As Paleoproterozoic ocean basins became more oxidizing, the iron cycle collapsed, and the major vector responsible for delivering silica to deepwater environments was lost. This model does not simply explain the occurrence of basinal chert in Late Archean and early Paleoproterozoic sedimentary basins; rather, in providing a mechanism for deepwater silica deposition, it places new constraints on the deposition of iron species as well.

In addition to the Transvaal Supergroup, the best studied Late Archean and earliest Paleoproterozoic iron formations are those from the Hamersley Province in Western Australia. Many observations reported from these deposits overlap with those described herein (Fig. 7) (Becker and Clayton, 1972; Baur et al., 1985; Krapež et al., 2003; Pickard et al., 2004). Although our model was developed explicitly to describe deposition of iron formations of the Campbellrand-Kuruman Complex, it may more generally capture the behavior of the iron cycle and origin of iron formation globally in Late Archean and early Paleoproterozoic ocean basins. Growing iron isotopic data from Late Archean and early Proterozoic sedimentary successions support the hypothesis of an active and conspicuous biological iron cycle (Yamaguchi et al., 2005; Archer and Vance, 2006; Johnson et al., 2008). In particular, the iron cycle favored by Johnson et al. (2008) to explain the differences in iron isotope ratios between different iron formation minerals shares many salient features with the model developed here to explain the silica distribution.

In principle, laboratory experiments and surface complexation models can suggest the expected range of $\mathrm{Si}: \mathrm{Fe}$ ratios in sedimenting particles predicted by our model (e.g., Sigg and Stumm, 1981; Davis et al., 2002). The quality of such predictions depends on limited experimental work and our equally limited knowledge of the chemical composition of the Late Archean and early Paleoproterozoic oceans. Nonetheless, given a dissolved $\mathrm{SiO}_{2}$ concentration of $60 \mathrm{mg} / \mathrm{L}$ (Siever, 1992), and assuming that the $\mathrm{pH}$ of Late Archean and early Paleoproterozoic oceans was between 7.5 and 8.5 (Grotzinger and Kasting, 1993), estimated sorption densities ( $\mathrm{mol} \mathrm{Si} / \mathrm{mol}$ Fe) fall between 0.85 and 1.0. These estimates overlap with, but are, on average, slightly lower than the ratios determined from bulk chemistry of iron formations (e.g., Klein 2005), which integrate data from chert-rich mesobands and intervening iron-rich laminations. Given the differences in expected behavior of both iron and silica during subsequent sedimentary diagenesis, however, it is difficult to benchmark properly these model predictions against ratios obtained from diagenetically stabilized iron formation. As iron reduction proceeded in sediments, soluble Fe(II) was largely free to diffuse back out of the sediments; with dissolved sulfide concentrations vanishingly low (e.g., Walker and Brimblecombe, 1985), the only species that could trap it quantitatively was carbonate, forming siderite. In contrast, the liberated silica, which did not undergo reductive dissolution, remained just as reactive and may have been preferentially concentrated in the sediments.

The complex diagenetic history displayed in iron formation and described in our model may have implications for the Archean fossil record. There are few reports of silicified fossils from Late Archean cherts, and described materials tend to be poorly preserved (Lanier, 1986; Klein

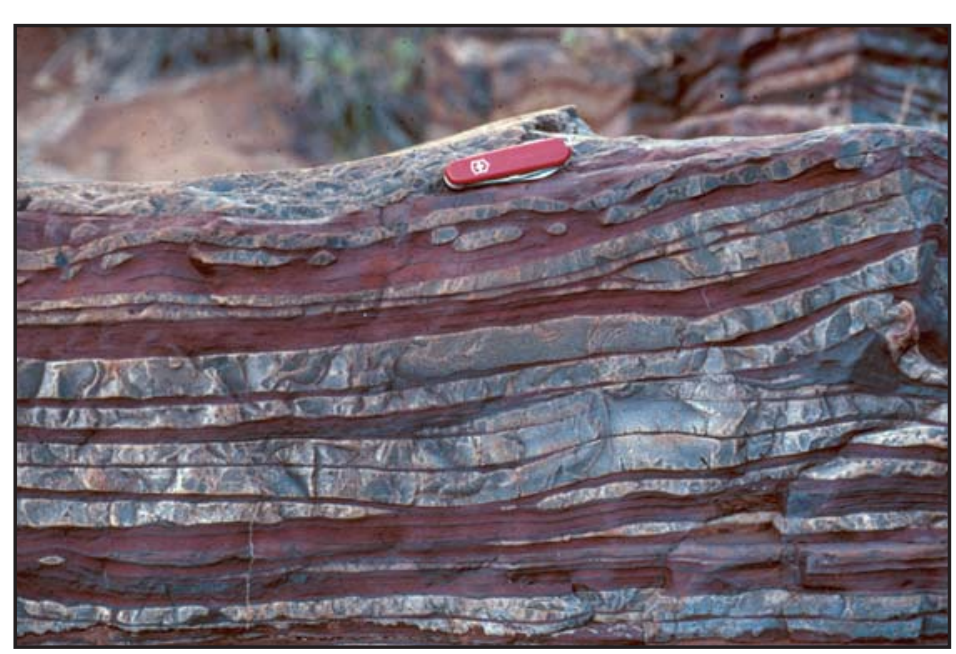

Figure 7. Example of early diagenetic chert development from the Brockman Iron Formation, Dales Gorge, Western Australia. 
et al., 1987; Lanier, 1986; Altermann and Schopf, 1995). If iron formation chert was a quantitatively important sink for oceanic silica, this may have influenced the nature, timing, and, therefore, the fossil preservation potential of chert formation in Late Archean tidal flat carbonates. This is in contrast to peritidal cherts in younger Proterozoic successions (e.g., Knoll, 1985), which commonly preserve microfossils. That stated, silicification of peritidal carbonates in the Campbellrand Subgroup did occur-perhaps commonly, later in the paragenetic sequence. This suggests that silica was present throughout the water column (in contrast with iron), and the sorption of silica onto ferric hydroxides was likely limited by available ferric hydroxideactive sites and not the availability of silica.

The lack of microfossils in Late Archean and early Paleoproterozoic iron formation stands in stark contrast to younger iron formations, which can be extraordinarily fossiliferous (e.g., Barghoorn and Tyler, 1965; Knoll and Simonson, 1981). This is just one of many features that distinguish the older Late Archean to earliest Paleoproterozoic iron formations from the younger circum-Superior Province and Nabberu Basin iron formations (Clout and Simonson, 2005). The two sets differ in their bulk chemical composition, petrologic textures, and depositional and tectonic settings. The younger Paleoproterozoic iron formations typically occur on convergent margins, possibly in linear foreland basins (Hoffman, 1987; Schneider et al., 2002). These formations commonly have a conspicuous shallow-water component (the widely recognized granular iron formations) that includes stromatolites and grainstones with current and orbital bed forms. This shallow component is more oxidized, containing abundant hematite and jasper, than its deepwater, laminated counterparts-just the opposite of relationships observed in the Campbellrand-Kuruman Complex. To the degree that iron formation deposits betray the location of the most abundant environmental oxidants at the time of their deposition, the Late Archean and earliest Paleoproterozoic examples point to iron oxides in deep sedimentary basins, whereas the younger iron formations imply $\mathrm{O}_{2}$ in the atmosphere and surface waters (Walker, 1987).

Drawn to the cessation of iron formation deposition after ca. 1.8 Ga, Canfield (1998) proposed that this transition came about as the oceans accumulated enough sulfide to titrate all available soluble $\mathrm{Fe}$ (II) as pyrite (see also Anbar and Knoll, 2002). This notwithstanding, we stress that iron formations themselves suggest an earlier transition. Coincident (given available time constraints) with the appearance of environmental oxygen ca. 2.4 Ga (Bekker et al., 2004), iron formations largely disappear from the geologic record only to return later in a pulse ca. $1.9 \mathrm{Ga}$ (Fig. 1) (Isley and Abbott, 1999). Whether this was associated with a middle Paleoproterozoic decline in atmospheric oxygen (e.g., Canfield, 2005 ) is still unclear. We do know, however, that this recursion was not simply a return to conditions like those in Late Archean marine basins. The distinctive nature of younger iron formations documents a world that does not seem to have existed earlier.

Given our hypothesis of a ferric hydroxide silica shuttle operating in Late Archean ocean basins, there are several things that we would like to understand better. How, for example, might such a process affect the fractionation of both rare earth elements (e.g., Köppenkastrop et al., 1991) and Ge relative to Si (e.g., Hammond et al., 2000; Anders et al., 2003; Pokrovsky et al., 2006), and does this require reinterpretation of geochemical proxies? Also, how does silica adsorption affect rates and mechanisms of biological iron reduction? Iron-reducing bacteria can access and reduce Fe(III) from a wide array of hydroxide and clay minerals (Lovley et al., 2004; Crowe et al., 2007). When grown on a ferrihydrite substrate containing 1 and $5 \mathrm{~mol} \%$ silica, Shewanella putrefaciens CN32 exhibited no change in iron reduction rate (Kukkadapu et al., 2004). Does this hold for higher adsorbed silica concentrations? Of the variety of known biological iron-reducing mechanisms, does the presence of adsorbed silica favor a particular strategy? Future work to answer these and other questions posed here should provide further insight into the origin of iron formation and its significance for Archean geobiology.

Today, diatoms are dominant primary producers, and, as such, the oceanic cycles of silica and carbon are tightly bound. The sedimentary record of chert indicates that this was not true for most of Earth's history. However, the views of iron formation espoused here suggest that, in Late Archean and early Paleoproterozoic oceans, the cycles of silica and carbon were once coupled in a different fashion, with iron as the crucial link.

\section{ACKNOWLEDGMENTS}

We thank John Higgins, Paul Hoffman, Ann Pearson, and Ben Kotrc for helpful discussions, and the Agouron Institute for funding. This work benefited by insightful reviews from Bruce Simonson and Bryan Krapež. Half cores of GKP01, GKF01, and BH1-Sacha are currently housed at the Council for Geoscience in Tshwane (formerly Pretoria), Gauteng Province, South Africa. Cores GKP01 and GKF01 were collected as part of the Agouron Drilling Project (http://agouron.spectraconsulting.co.za).

\section{REFERENCES CITED}

Altermann, W., and Nelson, D.R., 1998, Sedimentation rates, basin analysis and regional correlations of three Neo- archean and Paleoproterozoic sub-basins of the Kaapvaal Craton as inferred from precise U-Pb zircon ages from volcani-clastic sediments: Sedimentary Geology, v. 120, p. 225-256, doi: 10.1016/S0037-0738(98)00034-7.

Altermann, W., and Schopf, J.W., 1995, Microfossils from the Neoarchean Campbell Group, Griqualand West sequence of the Transvaal Supergroup, and their paleoenvironmental and evolutionary implications: Precambrian Research, v. 75, p. 65-90, doi: 10.1016/0301-9268(95)00018-Z.

Altermann, W., and Siegfried, H.P., 1997, Sedimentology and facies development of an Archean shelf: Carbonate platform transition in the Kaapvaal Craton, as deduced from a deep borehole at Kathu, South Africa: Journal of African Earth Sciences, v. 24, p. 391-410, doi: 10.1016/ S0899-5362(97)00051-1.

Amthor, J.E., Ramseyer, K., Faulkner, T., and Lucas, P., 2005 , Stratigraphy and sedimentology of a chert reservoir at the Precambrian-Cambrian boundary: The Al Shomou Silicilyte: South Oman Salt Basin: Geoarabia, v. 10 , p. 89-122.

Anbar, A.D., and Knoll, A.H., 2002, Proterozoic ocean chemistry and evolution: A bioinorganic bridge?: Science, v. 297, p. 1137-1142, doi: 10.1126/science.1069651.

Anders, A.M., Sletten, R.S., Derry, L.A., and Hallet, B., 2003 , Germanium/silicon ratios in the Copper River Basin, Alaska: Weathering and partitioning in periglacial versus glacial environments: Journal of Geophysical Research, v. 108, 6005, doi: 10.1029/2003JF000026.

Archer, C., and Vance, D., 2006, Coupled Fe and S isotopic evidence for Archean microbial Fe(III) and sulfate reduction: Geology, v. 34, p. 153-156, doi: 10.1130/G22067.1.

Armstrong, R.A., Compston, W., Retief, E.A., Williams, I.S., and Welke, H.J., 1991, Zircon ion micropobe studies bearing on the afe and evolution of the Witwatersrand triad: Precambrian Research, v. 53, p. 243-266.

Barghoorn, E.S., and Tyler, S.A., 1965, Microorganisms from the Gunflint Chert: Science, v. 147, p. 563-577, doi: 10.1126/science.147.3658.563.

Barley, M.E., Pickard, A.L., and Sylvester, P.J., 1997, Emplacement of a large igneous province as a possible cause of banded iron formation 2.45 billion years ago: Nature, v. 385, p. 55-58, doi: 10.1038/385055a0.

Barley, M.E., Bekker, A., and Krapež, B., 2005, Late Archean to early Paleoproterozoic global tectonics, environmental change and the rise of atmospheric oxygen: Earth and Planetary Science Letters, v. 238, p. 156-171, doi: 10.1016/j.eps1.2005.06.062.

Barton, E.S., Altermann, W., Williams, I.S., and Smith, C.B., 1994, U-Pb zircon age for a tuff in the Campbell Group, Griqualand West Sequence, South Africa: Implication for Early Proterozoic rock accumulation rates: Geology, v. 22, p. 343-346, doi: 10.1130/0091-7613(1994) 022<0343:UPZAFA >2.3.CO;2.

Barton, J.M., Jr., Blignaut, E., Salnikova, E.B., and Kotov, A.B., 1995, The stratigraphic position of the Buffelsfontein Group based on field relationships and geochemical and geochronological data: South African Journal of Geology, v. 98, p. 386-392.

Bau, M., and Möller, P., 1993, Rare earth element systematics of the chemically precipitated component in Early Precambrian iron formations and the evolution of the terrestrial atmosphere-hydrosphere-lithosphere system: Geochimica et Cosmochimica Acta, v. 57, p. 2239-2249, doi: 10.1016/0016-7037(93)90566-F.

Baur, M.E., 1978, Thermodynamics of heterogeneous ironcarbon systems: Implications for the terrestrial primitive reducing atmosphere: Chemical Geology, v. 22, p. 189206, doi: 10.1016/0009-2541(78)90031-1.

Baur, M.E., Hayes, J.M., Studley, S.A., and Walter, M.R., 1985, Millimeter-scale variations of stable isotope abundances in carbonates from banded iron-formations in the Hamersley Group of Western Australia: Economic Geology and the Bulletin of the Society of Economic Geologists, v. 80, p. 270-282.

Becker, R.H., and Clayton, R.N., 1972, Carbon isotopic evidence for the origin of a banded iron-formation in Western Australia: Geochimica et Cosmochimica Acta, v. 36 , p. 577-595, doi: 10.1016/0016-7037(72)90077-4.

Bekker, A., Holland, H.D., Wang, P.L., Rumble, D., Stein, H.J., Hannah, J.L., Coetzee, L.L., and Beukes, N.J. 2004, Dating the rise of atmospheric oxygen: Nature, v. 427 , p. $117-120$, doi: 10.1038 /nature 02260 . 
Beukes, N.J., 1973, Precambrian iron formations of southern Africa: Economic Geology and the Bulletin of the Society of Economic Geologists, v. 68, p. 960-1004.

Beukes, N.J., 1984, Sedimentology of the Kuruman and Griquatown iron-formations, Transvaal Supergroup, Griqualand West, South Africa: Precambrian Research, v. 24, p. 47-84, doi: 10.1016/0301-9268(84)90069-X.

Beukes, N.J., 1987, Facies relations, depositional environments and diagenesis in a major early Proterozoic stromatolitic carbonate platform to basinal sequence, Campbellrand Subgroup, Transvaal Supergroup, southern Africa: Sedimentary Geology, v. 54, p. 1-46, doi: 10.1016/0037-0738(87)90002-9.

Beukes, N.J., and Klein, C., 1992, Models for iron-formation deposition, in Schopf, J.W., and Klein, C., eds., The Proterozoic Biosphere: A Multidisciplinary Study: Cambridge, UK, Cambridge University Press, p. 147-151.

Beukes, N.J., Klein, C., Kaufman, A.J., and Hayes, J.M., 1990, Carbonate petrography, kerogen distribution, and carbon and oxygen isotope variations in and early Proterozoic transition from limestone to iron formation deposition, Transvaal Supergroup, South Africa: Economic Geology and the Bulletin of the Society of Economic Geologists, v. 85, p. 663-690.

Blake, T.S., and Barley, M.E., 1992, Tectonic evolution of the late Archaean to early Proterozoic Mount Bruce Megasequence Set, Western Australia: Tectonics, v. 11 p. 1415-1425, doi: 10.1029/92TC00339.

Bohrmann, G., Abelmann, A., Gersonde, R., Hubberten, H., and Kuhn, G., 1994, Pure siliceous ooze, a diagenetic environment for early chert formation: Geology, v. 22, p. 207-210, doi: 10.1130/0091-7613(1994)022<0207: PSOADE $>2.3 . \mathrm{CO} ; 2$.

Braterman, P.S., Cairns-Smith, A.G., and Sloper, R.W. 1983, Photo-oxidation of hydrated $\mathrm{Fe}^{2+}$-significance for banded iron formations: Nature, v. 303, p. 163-164, doi: $10.1038 / 303163 \mathrm{a} 0$.

Braterman, P.S., Cairns-Smith, A.G., and Sloper, R.W., 1984, Photo-oxidation of iron (II) in water between $\mathrm{pH}$ 7.4 and 4.0: Journal of the Chemical Society, Dalton Transactions: Inorganic Chemistry, p. 1441-1445, doi 10.1039/dt9840001441

Brocks, J.J., Buick, R., Logan, G.A., and Summons, R.E., 2003a, Composition and syngeneity of molecular fossils from the 2.78-2.45 billion-year-old Mount Bruce Supergroup, Pilbara Craton, Western Australia: Geochimica et Cosmochimica Acta, v. 67, p. 4289-4319, doi: 10.1016/S0016-7037(03)00208-4.

Brocks, J.J., Buick, R., Summons, R.E., and Logan, G.A., 2003b, A reconstruction of Archean biological diversity based on molecular fossils from the 2.78-2.45 billion-year-old Mount Bruce Supergroup, Hamersley Basin, Western Australia: Geochimica et Cosmochimica Acta, v. 67, p. 4321-4335, doi: 10.1016/S00167037(03)00209-6.

Brown, D.A., Gross, G.A., and Sawicki, J.A., 1995, A review of the microbial geochemistry of banded iron-formations: Canadian Mineralogist, v. 33, p. 1321-1333.

Buick, R., 1992, The antiquity of oxygenic photosynthesis: Evidence from stromatolites in sulphate-deficient Archaean lakes: Science, v. 255, p. 74-77, doi 10.1126/science. 11536492 .

Buick, R., and Knoll, A.H., 1999, Acritarchs and microfossils from the Mesoproterozoic Bangemall Group, northwestern Australia: Journal of Paleontology, v. 73 p. 744-764.

Button, A., 1973, The stratigraphic history of the Malmani dolomite in the eastern and north-eastern Transvaal: Geological Society of South Africa Transactions, v. 76, p. 229-247.

Cairns-Smith, A.G., 1978, Precambrian solution photochemistry, inverse segregation, and banded iron formations: Nature, v. 276, p. 807-808, doi: 10.1038/276807a0.

Canfield, D.E., 1998, A new model for Proterozoic ocean chemistry: $\mathrm{N}$ ature, v. 396, p. 450-453, doi: 10.1038/24839.

Canfield, D.E., 2005, The early history of atmospheric oxygen: Annual Review of Earth and Planetary Sciences, v. 33, p. 1-36, doi: 10.1146/annurev.earth.33. 092203.122711

Canfield, D.E., Rosing, M.T., and Bjerrum, C., 2006, Early anaerobic metabolisms: Philosophical Transactions of the Royal Society of London, Ser. B, Biological Sciences, v. 361, p. 1819-1836, doi: 10.1098/rstb.2006.1906.
Cloud, P.E., 1968, Atmospheric and hydrospheric evolution on the primitive Earth: Science, v. 160, p. 729-736, doi: 10.1126/science. 160.3829 .729 .

Cloud, P.E., 1973, Paleoecological significance of the banded iron-formation: Economic Geology and the Bulletin of the Society of Economic Geologists, v. 68, p. 1135-1143.

Clout, J.M.F., and Simonson, B.M., 2005, Precambrian iron formations and iron formation-hosted iron ore deposits: Economic Geology, 100th Anniversary Vol., p. 215-250.

Crowe, S.A., Roberts, J.A., Weisner, C.G., and Fowle, D.A., 2007, Alteration of iron-rich lacustrine sediments by dissimilatory iron-reducing bacteria: Geobiology, v. 5 , p. $63-73$

Davis, C.C., Knocke, W.F., and Edwards, M., 2001, Implications of aqueous silica sorption to iron hydroxide: Mobilization of iron colloids and interference with sorption of arsenate and humic substances: Environmental Science \& Technology, v. 35, p. 3158-3162, doi: 10.1021/es0018421.

Davis, C.C., Chen, H., and Edwards, M., 2002, Modeling silica sorption to iron hydroxide: Environmental Science \& Technology, v. 36, p. 582-587, doi: 10.1021/es010996t.

Derry, L.A., and Jacobsen, S.B., 1990, The chemical evolution of Precambrian seawater: evidence from REEs in banded iron formation: Geochimica et Cosmochimica Acta, v. 54, p. 2965-2977, doi: 10.1016/0016-7037(90) 90114-Z.

Dimroth, E., 1976, Aspects of the sedimentary petrology of cherty iron formation, in Wolf, K.H., ed., Handbook of Strata-Bound and Stratiform Ore Deposits: Amsterdam, Elsevier, v. 7, p. 203-254.

Dobson, D.P., and Brodholt, J.P., 2005, Subducted banded iron formations as a source of ultralow-velocity zones at the core-mantle boundary: Nature, v. 434, p. 371-374, doi: 10.1038 /nature 03430 .

Drever, J.I., 1974, Geochemical model for the origin of Precambrian banded iron formations: Geological Society of America Bulletin, v. 85, p. 1099-1106, doi: 10.1130/001 6-7606(1974)85<1099:GMFTOO >2.0.CO;2.

Ehrenreich, A., and Widdel, F., 1994, Anaerobic oxidation of ferrous iron by purple bacteria, a new type of phototrophic metabolism: Applied and Environmental Microbiology, v. 60, p. 4517-4526.

Emerson, D., and Revsbech, N.P., 1994, Investigation of an iron-oxidizing microbial mat community located near Aarhus, Denmark: Field studies: Applied and Environmental Microbiology, v. 60, p. 4022-4031.

Ewers, W.E., 1983, Chemical factors in the deposition and diagenesis of banded iron-formation, in Trendall, A.F., and Morris, R.C., eds., Iron Formation Facts and Problems: Amsterdam, Elsevier, p. 491-512.

Ewers, W.E., and Morris, R.C., 1981, Studies of the Dales Gorge Member of the Brockman Iron Formation: Economic Geology and the Bulletin of the Society of Economic Geologists, v. 76, p. 1929-1953.

Farquhar, J., Bao, H.M., and Thiemens, M., 2000, Atmospheric influence of Earth's earliest sulfur cycle: Science, v. 289, p. 756-758, doi: 10.1126/science.289.5480.756

Fein, J.B., Scott, S., and Rivera, N., 2002, The effect of $\mathrm{Fe}$ and $\mathrm{Si}$ adsorption on Bacillus subtilis cell walls: Insights into non-metabolic bacterial precipitation of silicate minerals: Chemical Geology, v. 182, p. 265 273, doi: 10.1016/S0009-2541(01)00294-7.

Fischer, W.W., Summons, R.E., and Pearson, A., 2005, Targeted genomic detection of biosynthetic pathways: Anaerobic production of hopanoid biomarkers by common sedimentary microbe: Geobiology, v. 3 , p. 33-40, doi: 10.1111/j.1472-4669.2005.00041.x.

Fischer, W.W., Schröder, S., Lacassie, J.P., Beukes, N.J., Goldberg, T., Strauss, H., Horstmann, U.E., Schrag, D.P., and Knoll, A.H., 2008, Isotopic constraints on the Late Archean carbon cycle from the Transvaal Supergroup along the western margin of the Kaapvaal Craton, South Africa: Precambrian Research (in press)

Frimmel, H.E., 2005, Archaean atmospheric evolution: Evidence from the Witwatersrand gold fields, South Africa: Earth-Science Reviews, v. 70, p. 1-46, doi: 10.1016/ j.earscirev.2004.10.003.

Garrels, R.M., 1987, A model for the deposition of the micro-banded Precambrian iron-formations: American Journal of Science, v. 287, p. 81-106

Garrels, R.M., Perry, E.A., Jr., and Mackenzie, F.T., 1973, Genesis of Precambrian iron-formations and the devel- opment of atmospheric oxygen: Economic Geology and the Bulletin of the Society of Economic Geologists, v. 68, p. 1173-1179.

Grotzinger, J.P., and Kasting, J.F., 1993, New constraints on Precampition: Journal of Geology, v. 101, p. $235-243$

Grotzinger, J.P., and Knoll, A.H., 1999, Stromatolites in Precambrian carbonates: Evolutionary mileposts of environmental dipsticks?: Annual Review of Earth and Planetary Sciences, v. 27 , p. $313-358$, doi: $10.1146 /$ annurev.earth.27.1.313.

Hamade, T., Konhauser, K.O., Raiswell, R., Goldsmith, S. and Morris, R.C., 2003, Using Ge/Si ratios to decouple iron and silica fluxes in Precambrian banded iron formations: Geology, v. 31, p. 35-38, doi: 10.1130/00917613(2003)031<0035:UGSRTD>2.0.CO;2.

Hammond, D.E., McManus, J., Berelson, W.M., Meredith, C., Klinkhammer, G.P., and Coale, K.H., 2000, Diagenetic fractionation of $\mathrm{Ge}$ and $\mathrm{Si}$ in reducing sediments The missing Ge sink and a possible mechanism to cause glacial/interglacial variations in oceanic $\mathrm{Ge} / \mathrm{Si}$ Geochimica et Cosmochimica Acta, v. 64, p. 2453 2465, doi: 10.1016/S0016-7037(00)00362-8.

Han, T.-M., 1978, Microstructures of magnetite as guides to its origin in some Precambrian iron-formations: Fortschritte der Mineralogie, v. 56, p. 105-142.

Harder, E.C., 1919, Iron-Depositing Bacteria and Their Geologic Relations: U.S. Geological Survey Professional Paper 113, 89 p.

Harder, H., 1964, Können Eisensäuerlinge die Genese der Lahn-Dill-Erze erklären?: Beiträge zur Mineralogie und Petrographie, v. 9, p. 379-422, doi: 10.1007/BF 02650155 .

Harder, H., 1965, Experimente zur "Ausfällung" der Kieselsäure: Geochimica et Cosmochimica Acta, v. 29, p. 429-442, doi: 10.1016/0016-7037(65)90037-2.

Harder, H., and Flehmig, W., 1970, Quarzsynthese bei tiefen Temperaturen: Geochimica et Cosmochimica Acta, v. 34, p. 295-305, doi: 10.1016/0016-7037(70)90107-9

Hartman, H., 1984, The evolution of photosynthesis and microbial mats: A speculation on the banded iron formations, in Cohen, Y., et al., eds., Microbial Mats: Stromatolites: New York, Alan R. Liss, p. 449-453.

Hoffman, P.F., 1987, Proterozoic foredeeps, foredeep mag matism, and Superior-type iron-formation in the Canadian shield, in Kröner, A., ed., Proterozoic Lithospheric Evolution: American Geophysical Union Geodynamics Ser., v. 17, p. 85-97.

Holland, H.D., 1973, The oceans: A possible source of iron in iron formations: Economic Geology and the Bulletin of the Society of Economic Geologists, v. 68 , p. 1169-1172.

Huang, C.P., 1975, The removal of aqueous silica from dilute aqueous solution: Earth and Planetary Science Letters, v. 27 , p. $265-274$, doi: 10.1016/0012-821X(75)90038-2.

Isley, A.E., 1995, Hydrothermal plumes and the delivery of iron to banded iron formation: Journal of Geology, v. 103 , p. 169-185.

Isley, A.E., and Abbott, D.H., 1999, Plume-related mafic volcanism and the deposition of banded iron formation: Journal of Geophysical Research, v. 104, p. 15,46115,477, doi: 10.1029/1999JB900066.

Jacobsen, S.B., and Pimentel-Klose, M.R., 1988, A Nd isotopic study of the Hamersley and Michipicoten banded iron formations: The source of REE and Fe in Archean oceans: Earth and Planetary Science Letters, v. 87, p. 29-44, doi: 10.1016/0012-821X(88)90062-3.

James, H.L., 1954, Sedimentary facies of iron formations: Economic Geology and the Bulletin of the Society of Economic Geologists, v. 49, p. 235-293.

Johnson, C.M., Beard, B.L., Klein, C., Beukes, N.J., and Roden, E.E., 2008, Iron isotopes constrain biologic and abiologic processes in banded iron formation genesis: Geochimica et Cosmochimica Acta, v. 72, p. 151-169.

Kappler, A., Pasquero, C., Konhauser, K.O., and Newman, D.K., 2005, Deposition of banded iron formations by anoxygenic phototrophic $\mathrm{Fe}(\mathrm{II})$-oxidizing bacteria: Geology, v. 33, p. 865-868, doi: 10.1130/G21658.1.

Kaufman, A.J., 1996, Geochemical and mineralogic effects of contact metamorphism on banded iron-formation: An example from the Transvaal Basin, South Africa: Precambrian Research, v. 79, p. 171-194, doi: 10.1016/ 0301-9268(95)00093-3 
Kaufman, A.J., Hayes, J.M., and Klein, C., 1990, Primary and diagenetic controls of isotopic compositions of iron-formation carbonates: Geochimica et Cosmochimica Acta, v. 54, p. 3461-3473, doi: 10.1016/0016-7037 (90)90298-Y.

Kharecha, P., Kasting, J., and Siefert, J., 2005, A coupled atmosphere-ecosystem model of the early Archean Earth: Geobiology, v. 3, p. 53-76, doi: 10.1111/j.14724669.2005.00049.x.

Kidder, D.L., and Erwin, D.H., 2001, Secular distribution of biogenic silica through the Phanerozoic: Comparison of silica-replaced fossils and bedded cherts at the series level: Journal of Geology, v. 109, p. 509-522, doi: $10.1086 / 320794$.

Kidder, D.L., and Mumma, S.A., 2003, Silica-replaced oolites, bedded shelf cherts and Paleozoic changes in the silica cycle: Sedimentary Geology, v. 162, p. 159166, doi: 10.1016/S0037-0738(03)00195-7.

Klein, C., 2005, Some Precambrian banded iron-formations (BIFs) from around the world: Their age, geologic setting, mineralogy, metamorphism, geochemistry, and origin: American Mineralogist, v. 90, p. 1473-1499, doi: $10.2138 / \mathrm{am} .2005 .1871$

Klein, C., and Beukes, N.J., 1989, Geochemistry and sedimentology of a facies transition from limestone to iron-formation deposition in the early Paleoproterozoic Transvaal Supergroup, South Africa: Economic Geology and the Bulletin of the Society of Economic Geologists, v. 84, p. 1733-1774.

Klein, C., and Beukes, N.J., 1992, Time distribution, stratigraphy, and sedimentologic setting, and geochemistry of Precambrian iron-formations, in Schopf, J.W., and Klein, C., eds., The Proterozoic Biosphere: A Multidisciplinary Study: Cambridge, UK, Cambridge University Press, p. 139-147.

Klein, C., Beukes, N.J., and Schopf, J.W., 1987, Filamentous microfossils in the Early Proterozoic Transvaal Supergroup: Their morphology, significance, and paleoenvironmental setting: Precambrian Research, v. 36, p. 81-84, doi: 10.1016/0301-9268(87)90018-0.

Knauth, L.P., 1994, Petrogenesis of chert, in Heaney, P., et al., eds., Silica: Physical Behavior, Geochemistry, and Materials Applications: Reviews in Mineralogy, Mineralogical Society of America, v. 29, p. 233-258.

Knoll, A.H., 1985, Exceptional preservation of photosynthetic organisms in silicified carbonates and silicified peats: Philosophical Transactions of the Royal Society of London-A, v. 311, p. 111-122, doi: 10.1098/ rstb.1985.0143.

Knoll, A.H., 1996, Archean and Proterozoic paleontology, in Jansonius, J., and McGregor, D.C., eds., Palynology: Principles and Applications: American Association of Stratigraphic Palynologists Foundation, v. 1, p. 51-80.

Knoll, A.H., and Simonson, B., 1981, Early Proterozoic microfossils and penecontemporaneous quartz cementation in the Sokoman Iron Formation, Canada: Science, v. 211, p. 478-480, doi: 10.1126/science.211.4481.478.

Knoll, A.H., Swett, K., and Mark, J., 1991, The Draken Conglomerate Formation: Paleobiology of a Proterozoic tidal flat complex: Journal of Paleontology, v. 65, p. 531-569.

Kooistra, W.H.C.F., Gersonde, R., Medlin, L.K., and Mann, D.G., 2007, The origin and evolution of the diatoms: Their adaptation to a planktonic existence, in Falkowski, P.G., and Knoll, A.H., eds., Evolution of Primary Producers in the Sea: Burlington, Vermont, Elsevier, p. 207-249.

Konhauser, K.O., Hamade, T., Raiswell, R., Morris, R.C., Ferris, F.G., Southam, G., and Canfield, D.E., 2002, Could bacteria have formed the Precambrian banded iron formations?: Geology, v. 30, p. 1079-1082, doi: 10.1130/ 0091-7613(2002)030<1079:CBHFTP>2.0.CO;2.

Konhauser, K.O., Lalonde, S.V., Amskold, L., and Holland, H.D., 2007a, Was there really an Archean phosphate crisis?: Science, v. 315 , p. 1234 , doi: $10.1126 /$ science. 1136328

Konhauser, K.O., Amskold, L., Lalonde, S.A., Posth, N.R., Kappler, A., and Anbar, A., 2007b, Decoupling photochemical $\mathrm{Fe}$ (II) oxidation from shallow-water BIF deposition: Earth and Planetary Science Letters, doi: 10.1016/j.epsl.2007.03.026.

Köppenkastrop, D., Decarlo, E.H., and Roth, M., 1991, A method to investigate the interaction of rare earth elements in aqueous solution with metal oxides: Journal of Radioanalytical and Nuclear Chemistry, v. 152, p. 337-346, doi: 10.1007/BF02104687.

Krapež, B., Barley, M.E., and Pickard, A.L., 2003, Hydrothermal and redimented origin of the precursor sediments to banded iron formation: Sedimentological evidence from the Early Proterozoic Brockman Supersequence of Western Australia: Sedimentology, v. 50, p. 979-1011, doi: 10.1046/j.1365-3091.2003.00594.x.

Kukkadapu, R.K., Zachara, J.M., Fredrickson, J.K., and Kennedy, D.W., 2004, Biotransformation of two-line silicaferrihydrite by a dissimilatory $\mathrm{Fe}$ (III)-reducing bacterium: Formation of carbonate green rust in the presence of phosphate: Geochimica et Cosmochimica Acta, v. 68, p. 2799-2814, doi: 10.1016/j.gca.2003.12.024.

Kump, L.R., and Seyfried, W.E., 2005, Hydrothermal Fe fluxes during the Precambrian: Effect of low oceanic sulfate concentrations and low hydrostatic pressure on the composition of black smokers: Earth and Planetary Science Letters, v. 235, p. 654-662, doi: 10.1016/j.epsl.2005.04.040.

LaBerge, G.L., Robbins, E.I., and Han, T.-M., 1987, A model for the biological precipitation of Precambrian iron-formations-A: Geological evidence, in Appel, P.W.U., and LaBerge, G.L., eds., Precambrian Iron Formations: Athens, Theophrastus Publications, p. 69-96.

Lanier, W.P., 1986, Approximate growth rates of Early Proterozoic microstromatolites as deduced by biomass productivity: Palaios, v. 1, p. 525-542, doi: 10.2307/3514705.

Lanier, W.P., 1986, Structure and morphogenesis of microstromatolites from the Transvaal Supergroup, South Africa: Journal of Sedimentary Petrology, v. 58, p. 89-99.

Lepp, H., and Goldich, S.S., 1964, Origin of Precambrian iron formations: Economic Geology and the Bulletin of the Society of Economic Geologists, v. 59, p. 1025-1060.

Lovley, D.R., Holmes, D.E., and Nevin, K.P., 2004, Dissimilatory $\mathrm{Fe}(\mathrm{III})$ and $\mathrm{Mn}(\mathrm{IV})$ reduction: Advances in Microbial Physiology, v. 49, p. 219-286, doi: 10.1016/ S0065-2911(04)49005-5.

Macgregor, A.M., 1927, The problem of the pre-Cambrian atmosphere: South African Journal of Science, v. 24, p. $155-172$

Maldonado, M., Carmona, M.C., Uriz, M.J., and Cruzado, A., 1999, Decline in Mesozoic reef-building sponges explained by silicon limitation: Nature, v. 401, p. 785 788, doi: $10.1038 / 44560$.

Maliva, R.G., 2001, Silicification in the Belt Supergroup (Mesoproterozoic), Glacier National Park, Montana, USA: Sedimentology, v. 48, p. 887-896, doi: 10.1046/ j.1365-3091.2001.00399.x.

Maliva, R.G., and Siever, R., 1989, Nodular chert formation in carbonate rocks: Journal of Geology, v. 97, p. 421-433.

Maliva, R.G., Knoll, A.H., and Siever, R., 1989, Secular change in chert distribution: A reflection of evolving biological participation in the silica cycle: Palaios, v. 4, p. 519-532, doi: $10.2307 / 3514743$

Maliva, R.G., Knoll, A.H., and Simonson, B.M., 2005, Secular change in the Precambrian silica cycle: Insights from chert petrology: Geological Society of America Bulletin, v. 117, p. 835-845, doi: 10.1130/B25555.1.

Miyano, T., and Beukes, N.J., 1984, Phase relations of stilpnomelane, ferriannite, and riebekite in very low-grade metamorphosed iron formations: Geological Society of South Africa Transactions, v. 87, p. 111-124

Morris, R.C., 1980, A textural and mineralogical study of the relationship of iron ore to banded iron-formation in the Hammersley Iron Province of Western Australia: Economic Geology and the Bulletin of the Society of Economic Geologists, v. 75, p. 184-209.

Morris, R.C., Thornber, M.R., and Ewers, W.E., 1980, Deepseated iron ores from banded-iron formation: Nature, v. 288 , p. $250-252$, doi: $10.1038 / 288250 \mathrm{a} 0$.

Murray, R.W., Jones, D.L., and Buchholtz ten Brink, M.R., 1992a, Diagenetic formation of bedded chert: Evidence from the chemistry of the chert-shale couplet: Geology, v. 20 , p. 271-274.

Murray, R.W., Buchholtz ten Brink, M.R., Gerlach, D.C., Russ, G.P., III, and Jones, D.L., 1992b, Rare earth, major, and trace element composition of Monterey and DSDP chert and associated host sediment: Assessing the influence of chemical fractionation during diagenesis: Geochimica et Cosmochimica Acta, v. 56, p. 2657 2671, doi: 10.1016/0016-7037(92)90351-I.

Ojakangas, R.W., 1983, Tidal deposits in the early Proterozoic basin of the Lake Superior region-The Palms and Pokegama Formations: Evidence for subtidal shelf deposition of Superior-type banded iron formation, in Medaris, L.G., Jr., ed., Early Proterozoic Geology of the Great Lakes Region: Geological Society of America Memoir 60, p. 49-66.

Okamoto, G., Okura, T., and Goto, K., 1957, Properties of silica in water: Geochimica et Cosmochimica Acta, v. 12 p. 123-132, doi: 10.1016/0016-7037(57)90023-6.

Ono, S., Eigenbrode, J.L., Pavlov, A.A., Kharecha, P., Rumble, D., III, Kasting, J.F., and Freeman, K.H., 2003, New insights in Archean sulfur cycle from mass-independent sulfur isotope records from the Hamersley Basin, Australia: Earth and Planetary Science Letters, v. 213 p. 15-30, doi: 10.1016/S0012-821X(03)00295-4.

Pavlov, A.A., and Kasting, J.F., 2002, Mass-independent fractionation of sulfur isotopes in Archean sediments: Strong evidence for an anoxic Archean atmosphere: Astrobiology, v. 2, p. 27-41, doi: 10.1089/153110702753621321.

Perry, E.C., Jr., and Lefticariu, L., 2003, Formation and geochemistry of Precambrian cherts, in McKenzie, F.T. ed., Volume 7, Sediments, Diagenesis, and Sedimentary Rocks, of Holland, H., and Turekian, K., eds., Treatise on Geochemistry: Amsterdam, Elsevier, p. 99-113.

Perry, E.C., Jr., and Tan, F.C., 1972, Significance of oxygen and carbon isotope variations in early Precambrian cherts and carbonate rocks of Southern Africa: Geological Society of America Bulletin, v. 83, p. 647-664, doi: 1 0.1130/0016-7606(1972)83[647:SOOACI]2.0.CO;2.

Pickard, A.L., 2003, SHRIMP U-Pb zircon ages for the Paleoproterozoic Kuruman Iron Formation, Northern Cape Province, South Africa: Evidence for simultaneous BIF deposition on Kaapvaal and Pilbara Cratons: Precambrian Research, v. 125 , p. 275-315, doi 10.1016/S0301-9268(03)00113-X

Pickard, A.L., Barley, M.E., and Krapež, B., 2004, Deepmarine depositional setting of banded iron formation: Sedimentological evidence from interbedded clastic sedimentary rocks in the early Proterozoic Dales Gorge Member of Western Australia: Sedimentary Geology, v. 170, p. 37-62, doi: 10.1016/j.sedgeo.2004.06.007.

Pokrovsky, O.S., Pokrovski, G.S., Schott, J., and Galy, A. 2006, Experimental study of germanium adsorption on goethite and germain coprecipitation with iron hydroxide: X-ray absorption fine structure and macroscopic characterization: Geochimica et Cosmochimica Acta, v. 70, p. 3325-3341, doi: 10.1016/j.gca.2006.04.012.

Rashby, S.E., Sessions, A.L., Summons, R.E., and Newman, D.K., 2007, Biosynthesis of 2-methylbacteriohopanepolyols by an anoxygenic phototroph: Proceedings of the National Academy of Sciences of the United States of America, v. 104, p. 15,099-15,104, doi: 10.1073/ pnas.0704912104.

Rasmussen, B., and Buick, R., 1999, Redox state of the Archean atmosphere: Evidence from detrital heavy minerals in ca. 3250-2750 Ma sandstones from the Pilbara Craton, Australia: Geology, v. 27, p. 115-118, doi: 10.11 30/0091-7613(1999)027<0115:RSOTAA $>2.3 . C O ; 2$

Rye, R., and Holland, H.D., 1998, Paleosols and the evolution of atmospheric oxygen: A critical review: American Journal of Science, v. 298, p. 621-672.

Schneider, D.A., Bickford, M.E., Cannon, W.F., Schulz, K.J., and Hamilton, M.A., 2002, Age of volcanic rocks and syndepositional iron formations, Marquette Range Supergroup: Implications for the tectonic setting of the Paleoproterozoic iron formations of the Lake Superior region: Canadian Journal of Earth Sciences, v. 39, p. 999-1012, doi: 10.1139/e02-016.

Schröder, S., Lacassie, J.P., and Beukes, N.J., 2006, Stratigraphic and geochemical framework of the Agouron drill cores, Transvaal Supergroup (NeoarcheanPaleoproterozoic, South Africa): South African Journal of Geology, v. 109, p. 23-54, doi: 10.2113/ gssajg.109.1-2.23.

Schubert, J.K., Kidder, D.L., and Erwin, D.H., 1997, Silicareplaced fossils through the Phanerozoic: Geology, v. 25 , p. 1031-1034, doi: 10.1130/0091-7613(1997)025 $<$ 1031:SRFTTP>2.3.CO;2.

Siever, R., 1957, The silica budget in the sedimentary cycle: American Mineralogist, v. 42, p. 821-841.

Siever, R., 1991, Silica in the oceans: Biological-geochemical interplay, in Schneider, S., and Boston, P.J., eds., Scientists on Gaia: Cambridge, Massachusetts, MIT Press, p. 287-295. 
Siever, R., 1992, The silica cycle in the Precambrian: Geochimica et Cosmochimica Acta, v. 56, p. 3265-3272, doi: 10.1016/0016-7037(92)90303-Z.

Sigg, L., and Stumm, W., 1981, The interaction of anions and weak acids with the hydrous goethite $(\alpha-\mathrm{FeOOH})$ surface: Colloids and Surfaces, v. 2, p. 101-117, doi 10.1016/0166-6622(81)80001-7.

Simonson, B.M., 1985, Sedimentological constraints on the origins of Precambrian iron-formations: Geological Society of America Bulletin, v. 96, p. 244-252, doi: 10 1130/0016-7606(1985)96<244:SCOTOO >2.0.CO;2.

Simonson, B.M., 2003, Origin and evolution of large Precambrian iron formations, in Chan, M.A., and Archer, A.W., eds., Extreme Depositional Environments: Mega End Members in Geologic Time: Geological Society of America Special Paper 370, p. 231-244.

Simonson, B.M., and Hassler, S.W., 1996, Was the deposition of large Precambrian iron formations linked to major marine transgressions?: Journal of Geology, v. 104 , p. $665-676$.

Sumner, D.Y., 1995, Facies, paleogeography, and carbonate precipitation on the Archean (2520 Ma) Campbellrand-Malmani Platform, Transvaal Supergroup, South Africa, [Ph.D. thesis]: Cambridge, Massachusetts Institute of Technology, $514 \mathrm{p}$.

Sumner, D.Y., 1997, Carbonate precipitation and oxygen stratification in Late Archean seawater as deduced from facies and stratigraphy of the Gamohaan and Frisco formations, Transvaal Supergroup, South Africa: American Journal of Science, v. 297, p. 455-487.

Sumner, D.Y., and Beukes, N.J., 2006, Sequence stratigraphic development of the Neoarchean Transvaal carbonate platform, Kaapvaal Craton, South Africa: South African Journal of Geology, v. 109, p. 11-22, doi: 10.2113/gssajg.109.1-2.11.

Sumner, D.Y., and Bowring, S.A., 1996, U-Pb geochronologic constraints on deposition of the Campbellrand
Subgroup, Transvaal Supergroup, South Africa: Precambrian Research, v. 79 , p. 25-35, doi: $10.1016 / 0301-$ 9268(95)00086-0.

Swedlund, P.J., and Webster, J.G., 1999, Adsorption and polymerization of silicic acid on ferrihydrite, and its effect on arsenic adsorption: Water Research, v. 33, p. 3413-3422, doi: 10.1016/S0043-1354(99)00055-X.

Tréguer, P., Nelson, D.M., Van Bennekom, A.J., DeMaster, D.J., Leynaert, A., and Quéguiner, B., 1995, The silica balance in the world ocean: A reestimate: Science, v. 268 , p. $375-379$, doi: $10.1126 /$ science.268.5209.375

Trendall, A.F., 1983, Introduction, in Trendall, A.F., and Morris, R.C., eds., Iron Formation Facts and Problems: Amsterdam, Elsevier, p. 1-11.

Trendall, A.F., 2002, The significance of iron-formation in the Precambrian stratigraphic record, in Altermann, W., and Cocoran, P., eds., Precambrian Sedimentary Environments: International Association of Sedimentologists Ser., v. 33, p. 33-66.

Trendall, A.F., and Blockley, J.G., 1970, The iron formations of the Precambrian Hammersley Group, Western Australia: With special reference to the associated crocidolite: Geological Survey of Western Australia Bulletin, v. 119,366 p.

Trendall, A.F., and Morris, R.C., eds., 1983, Iron Formation Facts and Problems: Amsterdam, Elsevier, 558 p.

Walker, J.C.G., 1984, Suboxic diagenesis in banded iron formations: Nature, v. 309, p. 340-342, doi: 10.1038/ 309340a0.

Walker, J.C.G., 1987, Was the Archean biosphere upside down?: Nature, v. 329, p. 710-712, doi: 10.1038/329710a0.

Walker, J.C.G., and Brimblecombe, P., 1985, Iron and sulfur in the pre-biologic ocean: Precambrian Research, v. 28 , p. 205-222, doi: 10.1016/0301-9268(85)90031-2.

Walker, J.C.G., Hays, P.B., and Kasting, J.F., 1981, A negative feedback mechanism for the long-term stabiliza- tion of Earth's surface temperature: Journal of Geophysical Research, v. 86, p. 9776-9782, doi: 10.1029/ JC086iC10p09776.

Walraven, F., and Martini, J., 1995, Zircon Pb-evaporation age determinations of the Oak Tree Formation, Chuniespoort Group, Transvaal Sequence: Implications for the Transvaal-Griqualand West basin correlations: South African Journal of Geology, v. 98, p. 58-67.

Widdel, F., Schnell, S., Heising, S., Ehrenreich, A., Assmus, B., and Schink, B., 1993, Ferrous iron oxidation by anoxygenic phototrophic bacteria: Nature, v. 362 , p. 834-836, doi: 10.1038/362834a0.

Xiong, J., Fischer, W.M., Inoue, K., Nakahara, M., and Bauer, C.E., 2000, Molecular evidence for the early evolution of photosynthesis: Science, v. 289, p. 1724 1730, doi: 10.1126/science.289.5485.1724.

Yamaguchi, K.E., Johnson, C.M., Beard, B.L., and Ohmoto, H., 2005, Biogeochemical cycling of iron in the ArcheanPaleoproterozoic Earth: Constraints from iron isotope variations in sedimentary rocks from the Kaapvaal and Pilbara Cratons: Chemical Geology, v. 218, p. 135-169, doi: 10.1016/j.chemgeo.2005.01.020.

Yee, N., Phoenix, V.R., Konhauser, K.O., Benning, L.G., and Ferris, F.G., 2003, The effect of cyanobacteria on silica precipitation at neutral $\mathrm{pH}$ : Implications for bacterial silicification in geothermal hot springs: Chemical Geology, v. 199, p. 83-90, doi: 10.1016/S0009-2541(03)00120-7.

Manuscript Received 14 SePtember 2007 ReVISED Manuscript ReCEIVED 9 APRIL 2008 MANUSCRIPT ACCEPTED 10 APRIL 2008

Printed in the USA 